

\section{STUDIES ON}

THE PROCESSING OF WHAAT GERM

A Thesis

\section{by}

Charles Victor Lusena

Submitted to the Faculty of Graduate Studies and Research in partial fulfilment of the requirements for the Degree of Master of Solence.

Moaill University

September $\quad 1944$ 


\section{ACKNOWLEDGEMENTS}

I wish to express my thanks to Dr. W.D. Moparlane for the facilities extended and for helpful oriticism; my thanks are also due to Dr. W.F. Parker, Ogilvie Flour M1IIs Company IImited, for his raluable advice. 


\section{TABLE OF CONTENTS}

\section{PART A: INTRODUCTION}

Page

I. GENERAL 1

II. ENZYME SYSTEMS IN WHEAT GERM

(a) General 3

(b) Papain-like enzymes 5

(c) Papain activation 6

(d) Glutathione 8

III. WHEAT GERM AS A FOOD 9

(a) Wheat germ cereals 9

(b) Wheat germ in baking 10

$\begin{array}{ll}\text { IV. PURPOSE OF THE PRESENT STUDY } & 14\end{array}$

\section{PART B: METHODS}

I. DETERMINATION OF IIPOXIDASE ACTIVITY

(8) Goneral 15

(b) Procedure 15

(c) Absorption and calibration curves 17

(d) Study of conditions for the determination 20

(1) General 20

(2) Preparation of the enzyme extract 20

(3) Reaction Time 21

II. DETERMINATION OF PROTEOLYTIC ACTIVITY 21

(a) Goneral 21 
Page

(b) Procedure 22

(c) Absorption spectrum and calibration curves 24

(d) Study of conditions for the determination 27

(1) Sample size 27

(2) $\mathrm{pH} \quad 28$

(3) Temperature 28

(4) Time 29

(5) Activators 30

III. FAT-PEROXIDE DETERMINATION 31

IV. STORAGE TESTS 32

V. BAKING TESTS

PART C: EXPERIMENTAL

I. THE PREPARATION OF A CEREAL FOOD

(a) General $\quad 35$

(b) First trials $\quad 35$

(c) Successive moist and dry heat treatments 40

(d) Solvent treatments 43

(e) Solvent and steam treatments 48

(f) The use of a new equipment for the treatment
of wheat germ

II. THE USE OF TREATED WHEAT GERM IN BAKING 53

(a) General 53

(b) Biscult baking $\quad 54$

(c) Bread baking 54

-III. THE EFFECT OF TREATMENTS ON THE VITAMIN CONTENT OF WHEAT GERM 
IV. GLUTATHIONE AND THE ACTIVATION OF THE PROTEOLYTIC ENZYMES

(a) General 60

(b) The estimation of glutathione in wheat germ 61

(I) Procedure 61

(2) Extraction 63

(3) Precipitation 63

(4) Titration 65

(c) The effect of treatment of the germ on $1 \mathrm{ts}$ glutathione content 65

(d) Reactivation of the proteolytic enzymes by glutathione and cyanide

\section{PART D: DISCUSSION}

I. THE IMPORTANCE OF PEROXIDE CONTENT AND LIPOXIDASE ACTIVITY TO THE KEEPING QUALITY AND BAKING PROPERTIES OF WHEAT GERM

II. PROTEOLYTIC ENZYMES AND THE KEEPING QUALITY AND BAKING PROPERTIES OF WHEAT GERM

III. THE IMPORTANCE OF THE TREATMENT 


\section{IIST OF TABLES}

Table No.

Page

I. Proteolytic activity with varying amounts of wheat germ

II. Proteolytic Activity at various $\mathrm{pH}^{\prime} \mathrm{s} \quad 28$

III. The effect of temperature on digestion in light and dark

IV. The effect of incubation time on proteolytic activity

V. The effect of activators on proteolytic activity 31

VI. Peroxide content of treated wheat germ 36

VII. Analysis of samples before Storage Test No.I 37

VIII. Peroxide content after varying periods of Storage Test No.I

IX. Peroxide content of some samples from Storage Test No.2

X. Results of Storage Test No.3

XI. Storage Test No. 4

XII. Baking tests on samples treated for different lengths of time

XIII. Baking tests on samples from Storage Test No.5

XIV. Effect of Storage on the baking quality of treated wheat germ

XV. Thlamin content of wheat germ samples

XVI. The recovery of glutathione by precipitation with cadmium lactate

XVII. The glutathione content of treated wheat germ

XVIII. The effect of activators on proteolytic activity of wheat germ 


\section{IIST OF FIGURES}

Figure No.

1. Lipoxidase determination - absorption spectrum of ferric thiocyanate

page

2. Lipoxidase determination - calibration curve

3. Determination of proteolytic activity absorption spectrum of the blue colour

4. Determination of proteolytic activity calibration curve

5. Apparatus for the successive moist and dry heat treatment

6. Apparatus for the solvent process

7. Equipment for the treatment of wheat germ 
PART A

INTRODUCTION 


\section{General}

One of the most important post-war aims is a more adequate diet for all people. To achieve this, the production of each dietary essential will need to be carefully considered and the production of some commodities may have to be greatly increased if more people are to be adequately fed from approximately the same acreage. This investigation has sought to make cereal germs more acceptable as a human food and thereby to make available a rich source of the B-vitamins and a large amount of highest quality protein in addition to fat and vitamin $E$. The cereal germs have an additional significance in economy of production since they are plant products which do not need to be transformed by animals to give these important dietary essentials.

The germs of wheat and corn are the most important from the standpoint of quantity available. Both are by-products of the milling industry and are used as animal feed, generally as components of the bran and in limited amounts as a source of oil. This investigation was confined to studies on wheat germ.

The annual production of wheat germ, as such, in the States is estimated to be 30 to 50 million pounds. However, the present miling yield of about $0.5 \%$ indicates a potential production of about 150 million pounds of germ (35). The wheat kernel is reported (2) to contain 2.2 3.0\% of germ and therefore it is possible that, in the future, the milling yield and hence the potential production 
of wheat germ may be greatly increased. For Canada, assuming an annual production of 350 million bushels of wheat and a yield of only $0.5 \%$ of germ, the potential production of wheat germ is about 100 million pounds per annum.

The proximate composition of wheat germ as given by Schuette and Palmer (63) is as follows:

$\begin{array}{lcr}\text { Crude Protein } & 23.6 & -40.7 \\ \text { Ether Extract } & 6.0-13.5 \\ \text { Crude Fiber } & 1.6-4.7 \\ \text { Ash } & 3.9-6.4 \\ \text { Nitrogen-Free Extract } & 39.2-48.5 \\ \text { Calcium (Ca) } & 0.07 & \\ \text { Phosphora (P) } & 1.05 & \\ \text { Iron (Fe) } & 0.007\end{array}$

The low crude fiber and the high crude protein and ash are of special nutritional slgnificance. Grewe and Leclerc (36) have made an extensive review of the literature on the composition of wheat germ from different varieties of wheat. Wheat germ protein, as shown by Hove and Harrel (43), has a biological value for rats quite close to that of casein, skim milk and dried egg white and further it has excellent supplementary qualities.

In addition, wheat germ is an excellent source of the "vitamin-B-complex" as Munsell and De Veney report (57) and when added to bread increases considerably its content of 
these vitamins $(54,55)$, at a 20\% level it trebles the vitamin value of the loaf. Crampton and Ashton (23) in feeding trials with rats found a high value for the "vitamin-B-complex" content of wheat germ and the individual B-ritamin content of defatted wheat germ has been reported (75) as follows:

\begin{tabular}{|c|c|c|c|c|}
\hline Thlamin & $33 x$ & $\mu \cdot g$. & per & $g$ \\
\hline Riboflavin & 9 & $"$ & $"$ & \\
\hline Pantothenic Ac1d & 26 & $"$ & $"$ & \\
\hline Pyridoxine & 15 & $"$ & $"$ & \\
\hline Niacin & 80 & $"$ & $"$ & \\
\hline Biotin & 0.45 & $n$ & $"$ & \\
\hline Inositol & $2 \cdot !$ & $\mathrm{mg}$. & & \\
\hline
\end{tabular}

Pearce (59) has found no detectable loss of thiamin in wheat germ during storage.

Solvent extracted wheat-germ oll contains large amounts of vitamin $E(0.3-0.4 \%)$ as reported by Parker and McFarlane (58).

These analysis serve to indicate the high nutritive ralue of wheat germ and to emphasize the importance which should be attached to 1ts large-scale utilization as a human food.

\section{Fnayme Systems in Wheat Germ}

\section{(a) General}

Wheat germ constitutes a living system from which a whole plant will develop, and hence possesses an intricate system of enzymes and activators. These enzymes are 
responsible for many of the difficulties attending the use of th1s material as a food; it quickly develops "off-flavours" in storage and it liquifies the dough in bread making. Therefore, a thorough study of the enzyme systems might provide a solution to the two problems and lead to the creation of a stablilized wheat germ which could be used in the fortification of bread.

We will not be concerned here with carbohydrases since they cannot have any relation to the problem. Sumner (71) reports the presence of a considerable amount of lipoxidase in wheat germ so that fat oxidation might be a cause of the deterloration of wheat germ during storage. Sullivan, Near and Foley (70) conclude that the fat of fresh germ has little or no effect on the properties of patent flour as shown by farlnograph curver and baking tests. However, they observed that unsaturated fatty acids when exposed to oxygen have a deleterious effect on the baking qualities of the flour. Bull (20) reports that fat-free wheat germ does not possess Improved baking qualities. However, Pearce (59) did not find that peroxides increase during the storage of wheat germ and his results seem to indicate that proteln hydrolysis may be chiefly responsible for the spollage of wheat germ. Balls and Hale $(3,4,6)$ maintain that the wheat proteinases active in the baking process belong to the papain group and Jorgensen (46) has shown that a close analogy exists between papain and the wheat protelnases. Flohtl (29) also concluded that the wheat germ proteinases resemble papain in 
their properties.

$\Delta$ high degree of concentration and purification is required before an enzyme preparation from wheat, of even moderate activity, is obtained (5). There is no apparent distinction between latex-borme and other plant proteinases as such, possibly because the source of the latter may also have been a sjotem of latex vessels. Winnick, Davis and Greonberg (79), for example, emphasize the similarities between papain, bromelin and asclepain.

\section{(b) Papain-Iike Enzyme}

From the work of Bergmann and co-workers $(12,13,14)$ employing synthetic substrates, it will be realized that papain has a broad range of spociflcity since it hydrolyzed peptides derived from many different amino aclds. Behrens and Bergmann (10) give tentative evidence for the existence of more than one enzymatic component by comparing the actirity of sereral papain preparations towara l-leucineamide and carbobenzoxy-i soglutamine.

Balls and Lineweaver (7) have isolated a crystalline enzyme preparation from papain latex and they found that the ratio of milk-clotting activity to hemoglobin-digesting power varled with different papain fractions and concluded that papain may contain more than one enzyme. Jansen and Balls (45) 1solated a new enzyme from commercial papain which they called chymo-papain and with which they found the ratio of milk-clotting actirity to hemoglobin digestion to be exactIy twice that of orystaline papain. The quantity of 
chymo-papain present in crude latex is considerably greater than the papain content. Probably papain and chymo-papain are the same as the papain-peptidase I and papain-peptidase II of Bergmann et al. (13).

\section{(c) Papain Activation}

Since the discovery in 1903 by Vines (74) that papain could be activated by cyanide lons, there have been numerous experimental studies of the mechanism of this phenomenon. Mendel and Blood (5I) concluded that cyanide and other activators acted in a manner analogous to that of coenzymes, broadening the specificlty range of papain but this theory was subsequently abandoned.

Most of the known activators -- cysteine, glutathione, hydrogen sulphide, thloglycollc acid and sulphite -- are reducing agents and, accoreing to Bersin $(15,16)$, natural papain is inactirated by oxidizing agents and reactivated by these reducing agents. He has concluded that inactive papain represents the disulphide form of the enzyme and that the process of activation consists in a reduction of disulphide groups to sulphydryl groups.

According to Frankel (32) no cyanide lons were destroyed In the course of an enzymatic digestion and this precludes Its action as a reducing agent. Fruton and Bergmann (33) in the course of a purification of papain, observed that the precipitation of a cjanide-activated preparation by isopropyl alcohol resulted in nearly complete loss of actirity. The quantitative study of this behavior by means of synthetic sub- 
strates gave results which could not be reconclled with the oxidation-reduction theory. In order to explain these results the authors found it necessary to return to the coenzyme theory of Mendel and Blood and to assume that cyanide Ions combine with the "inactive" papain to form a dissociable cyanide-papain complex which represents the cyanide-activated enzyme. Since the disulphide-sulphydryl theory of papain activation postulates that the function of the activator is to reduce disulphlde groups, one would be forced to conclude that, regardiess of the actirator applied, the same actirated enzyme would result. On the other hand, from the co-enzyme theory, it may be expected that the rarious enzyme-activatior complexes, derlved from the same enzyme, would differ more or less in their specificities; and this is the case as shown by Fruton and Bergmann (33).

Finally, Bergmann (II) outlined a new theory based on sound experimental work, which can be expressed thus:

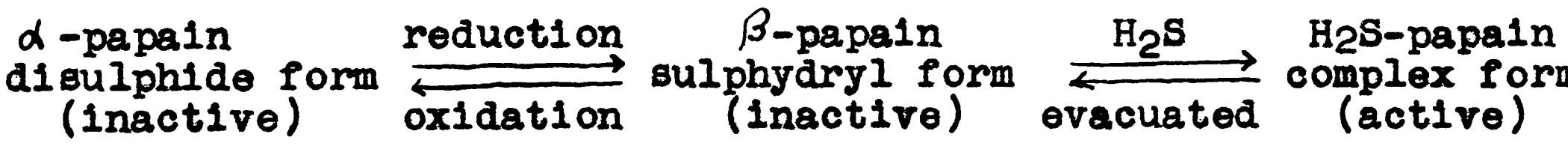

$\alpha$-Papain might be activated by hydrogen sulphide (not by cyanide 10ns) and when the hydrogen sulphlde is subsequently removed in-vacuo, a second inactive form $\beta$-papain is obtained which can be activated by cyanide ions. The fact that the activation of papain by hydrogen sulphide or cyanide ions may be reversed by evacuation, shows that two dissociable complexes are formed. 
The fact that the speciflcity of an intracellular proteinase is not rigidy determined, but may be altered in various ways by different activators, is of obvious significance in: the general problem of protein breakdown. While glutathione has been accepted as a possible, naturally occurring actirator, it is clear that other substances (cystelne, cystelne peptides, possibly ascorbic acid, etc.) shown to occur in living tissues are also potential activators.

\section{(d) Glutathione}

Glutathione was discovered about 50 years ago but was rediscovered in 1921 by Hopkins, who later devised a rapld and easy method (42) for 1solating it in a pure crystaline form from yeast. Glutathione is a tripeptide of glycine, glutamic acid and cysteine. Kendell, McKenzie and Mason (48) claim that the glycine is attached to the carboxyl group of the glutamic acid nearest to the amine group, and the cysteine is attached to the other carboxyl group of the glutamic acid molecule. Regnier (6I) has devised an improved method for isolating glutathione and Meldrum and Dixon (49) have made an excellent study of the properties of glutathione. Barron and singer (9) have studied the role of glutathione in various enzyme systems and found that it has some effect on pyruvate oxidase, pyruvate condensation enzyme, pyruvate dismutation enzyme, $\alpha$-ketoglutarate oxidase, malate oxidase, transaminase, monoamine oxidase, d-amino acid oxidase, I-glutamate oxidase, stearate oxidase, oleate oxidase, $\beta$-hydroxy butyrate oxidase, IIpase and native myosin. 
The role of glutathione in living cells seems to be to maintain the sulphydryl-containing enzyme systems in an actire state. Quastel and Wheatley $(60)$ suggest that the controlling action of glutathione on aeroblc fermentation is probably of significance in the normal metabolism of the cell. An important role of glutathione is the maintenance of the reducing activity of the cell which seems to be necessary, since synthesis in the cell is a reduction process, whereas oxidation leads to the breaking down of the cell compounds.

In 1937 Sullivan and Howe (67) 1solated 0.1 - $0.2 \%$ glutathione from wheat germ, although Sullivan, Howe and Schmalz (68) had obtained (by lodine titration) a value of $0.46 \%$ of glutathione in a very fresh and specially purified sample of wheat germ.

\section{Wheat Germ as a Food}

\section{(a) Wheat Germ CerealB}

"Tonik" Wheat Germ, a product of the V1oBin Corporation, Montecello, Illinols, is the fat-free residue and has good keeping quality. However, solvent extraction of the fat. In this case with ethylene dichloride, is a relatively expensive process and the product can only be used in baking bread in very limited quantities. Wanklyn and Stacey (77) patented a wheat germ food prepared by holding the wheat germ at about $57^{\circ} \mathrm{C}$. for elght hours in a closed vessel under a vacuum of 20-27 1n. of mercury; the object being to remove molsture without damaging the vitamins, etc. Another 
patented product (26) sald to be free from rancidity is prepared by mixing sodium chloride with fresh wheat germ, grinding this mixture to about the consistency of flour, then mixing with an inert non-fatty filler such as potato flour and finally drying the mixture.

Hertwig, secretary of the Committee on Foods of the American Medical Association (38), called attention to the palatability, pleasing and appetizing appearance, and the good keeping qualities of lightly toasted wheat germ. In a second article (39) Hertwig said that the addition of toasted wheat germ to flour for general baking purposes might deserve consideration for developing a new line of bakery good with supplemented nutritional values and thereby tend to increase flour consumption for the benefit of the milling industry and at the same time raise the vitamin level of the average diet.

\section{(b) Wheat Germ in Baking}

According to Rich (62), the poor baking qualities of the lower grade flours was due to contamination with germ particles and the improvement due to artificial maturation was caused by a reaction which apparently involves the oxidation of some constituent of the germ. The maturing effect seemed to be influenced to some extent by the protein content of the flour. A similar conclusion was arrived at by Flohil (29), and Geddes (34) found that adding germ to fifth midding flour markedly reduced its baking quality. Increasing the fermentation time or the addition of bromate and heating the germ before adding the bromate, reduced the harmful effect of 
the germ. Sullivan, Near and Foley (70) found that fresh wheat germ had a very deleterious effect on the baking quality of patent flour, but when stored with a relatively high moisture content and at room temperature, in a sealed container, wheat germ lost much of 1ts injurious action.

Grewe and LeClerc (37) reported that soaking wheat germ in water caused a marked improvement in 1ts bread-making properties when added to flour dough. The beneficial effect of this steeping process increased with increasing time up to six or eight hours. The addition of 2.5 or $5 \%$ of steeped germ gave a better bread than when no germ is used and 15 to 20 \% still produced a very satisfactory bread. Steeping increased the diastatic power and decreased the oxidizable substances. Contrary to this, Smith and Geddes (65) found that germ which had been steeped in water for six hours still had the same harmful effect, but if relatively large amounts of potassium bromate were added to the steeping-water, an improvement resulted. Following a suggestion by Hullet and Stern (44), the same authors found that by pre-fermentation of the germ, the injurious effect on the dough gradually disappeared as the time of pre-fermentation increased up to 4.5 hours and further improvement was obtained by adding bromate to the pre-fermented germ.

The effects on dough of oxidizing substances, or reducing substances, on proteases activated by sulphydryl groups, has been invertigated by several cereal chemists. Shen and Geddes (64) reviewed the literature on this subject, up to the second 
half of 1941 and more recent reviews have been prepared by rilon (27) and Stern (66). It is evident from these reviews that the problem is very complex, that many reactions take place, and it has still to be determined which are involved in the action of wheat germ on the properties of the dough. According to Jorgensen's theory $(46,47)$, oxidizing agents used in baking suppress the action of glutathione in activating the powerful but normally inactive proteolytic enzymes present in the dough. Balls and Hale (4) have shown that chlorine reduces flour proteolytic activity and they also concluded that similar effects are produced when an oxidant is added to the dough as a bread improver. This view was also supported by Flohil (29), by Melville and Shattock (50) and by many others.

At temperatures below $40^{\circ} \mathrm{C}$. large excess of bromate was necessary for the rapid oxidation of glutathione (81). The action of bromate as an improver in wheat flour dough is known to be gradual and this is explained by 1ts slow rate of oxidation. A small amount of oxidized glutathione (one part in 25,000) has a beneficial effect on dough (82). The improvement of balfing strength caused by the addition of bromate is not merely due to the suppression of the harmful effect of the protease activator, but can partly be explained by the subsequent presence of oxidized glutathione in the dough.

When Sullivan, Howe and Schmalz (68) first observed the harmful effect of glutathione, they cautioned against too 
narrow a view regarding the activation of proteolytic enzymes by substances containing the sulphydryl group, because many compounds, Inorganic as well as organic, can materially influence the colloidal behavior of the gluten protein by modifying the oxidation-reduction system. Similar suggestions were made later by Ford and Maiden (3I), Balls and Hale (5) and recently Suliivan, Howe, Schmalz and Astleford (69).

Hills and Ba1ley (40) found that papain digestion increased amylase activity of ungerminated barley approximately 100\% due to the proteolytic release of $\beta$-amylase associated with water-soluble materials. This might possibly be a secondary effect.

Stern (66), in a very recent experiment, showed the coexistence of an activation of the proteases by wheat germ extract and the direct effect of the extract on gluten. She also found a considerable amount of dehydrogenases in wheat germ and observed that fermentation speeded up their otherwise slow action. Nothing is yet known about the mechanism of this acceleration except that it involves the glutathione present in the yeast cells (44). This would explain the beneficial effect of pre-fermenting wheat germ before adding It to the dough and of prolonged fermentation of low-grade flours.

Meanwhlle Brown and Goddard (19) reported that the greater part of the cell respiration of wheat germ is mediated by Its cytochrome oxidase and found the typlcal absorption band of the oytochromes. The two extremes of the "Hydrogen 
Bucket Brigade" are therefore found in action and at one end the dehydrogenase promotes the oxidation of glutathione which proceeds beyond the disulphide stage.

\section{Purpose of the Present Study}

The practical aim of the present investigation was to make wheat germ more palatable, more stable and to produce a material which could be used to fortify bread with the B Complex and with protein of high blological value. It would appear to be a much sounder practice economically and nutritionally to fortify bread from a natural source. In the light of the above literature review, the fundamental approach to the problem includes (1) the controlled inactivation of the enzymes and (2) storage and baking tests on the products. 
PART B

METHODS 


\section{Determination of Iipoxidase Activity}

\section{(a) General}

An adaptation of Sumner's method (71) was made to sult our conditions for the analysis of wheat germ. In dilute water suspension fat peroxides oxidize ferrous iron, and the ferric iron formed can be determined colorimetically as the thlocyanate (80), according to the following equations:

$$
\begin{array}{lll}
-\mathrm{CH}-\mathrm{CH}- & +\mathrm{O}_{2} \stackrel{\text { Ilpoxidase }}{\longrightarrow}-\mathrm{CH}-\mathrm{CH}- \\
-\mathrm{CH}-\mathrm{CH}-+2 \mathrm{Fe}^{++}+2 \mathrm{H} \longrightarrow & -\mathrm{CH}-\mathrm{CH}-+2 \mathrm{Fe}^{+++} \\
\stackrel{\mathrm{OH}}{\mathrm{OH}} & \longrightarrow \mathrm{Fe}\left[\mathrm{Fe}(\mathrm{CNS})_{6}\right] \mathrm{red} \text { colour }
\end{array}
$$

In the determination of Iipoxidase activity by Sumer's method (7I) an aqueous enzyme extract is allowed to act for a certain time on the highly unsaturated linolelc acid and the amount of ferrous ion converted to ferric is measured colorimetically. A unit of lipoxidase is defined as "the activity which in the presence of $5 \mathrm{mg}$. of linolelc acid in the described mixture catalyses the reaction of one microgram of oxygen in one minute at $25^{\circ} \mathrm{C}$. and $\mathrm{pH} 7^{\prime \prime}$.

\section{(b) Procedure}

A 2.5 8. portion of finely ground wheat germ was welghed Into a 250-ml. Frlenmeyer 1lask; $100 \mathrm{ml}$. of distilled water added, and the flaek shaken in a mechanical shaker for half an hour. A portion was then centrifuged for 10 minutes in a 15-ml. centrifuge tube at 2000 revolutions per minute in a 
clinical centrifuge, giving a clear enzyme extract.

Meanwhlle into four 250-ml. Erlenmeyer flasks were placed:

(1) $5 \mathrm{ml}$. of acetone containing one $\mathrm{mg}$. of linoleic acid per ml. This solution was freshly prepared because linoletc acid oxidizes falrly rapidly in acetone solution and therefore an old solution gives high blank values.

(2) $5 \mathrm{ml}$. of citrate buffer, prepared by mixing $55 \mathrm{ml}$. of a solution of citric acid (2l,008 $\mathrm{g}$. per liter) and sodium hydroxide $(8 \mathrm{~g}$. per liter) with $45 \mathrm{ml}$. of 0.1 normal sodium hydroxide.

(3) $100 \mathrm{ml}$. of distilled water.

Two of these four llasks were used as blanks and to these $10 \mathrm{ml}$. of concentrated hydrochloric acid were immediately added. Then one $\mathrm{ml}$. of the enzyme extract was added to each of the four flasks and to the two test flasks, $10 \mathrm{ml}$. of concentrated hydrochloric acld were added after exactly 5 minutes to stop the enzyme action and to provide an acid medium for the oxidation of the ferrous 10ns. Then one ml. of a $5 \%$ solution of ferrous ammonium sulphate in $3 \%$ hydrochloric acid was added. After thoroughly mixing, $5 \mathrm{ml}$. aliquots from each flask were transferred to test tubes and, exactly 15 minutes after the addition of the ferrous salt, $5 \mathrm{ml}$. of $95 \%$ ethanol and $1 \mathrm{ml}$. of $20 \%$ ammonium thiocyanate were added, each tube was shaken and the red colour which developed was read with the Coleman spectrophotometer at $455 \mathrm{~m} \cdot \mu$. The calculation of lipoxidase activity was made from the equation: 
$\frac{(T-B) \times V \times 0}{F \theta \times t \times W}=T-B \times 280.3$ units per $g$.

$T=$ micrograms of ferric ions in test solution

B " " " "blank "

$V$ = volume of solution for enzyme digestion ( $121 \mathrm{ml}$. )

0 = atomic weight of oxygen (16)

$\mathrm{Fe}="$ "1ron (55.84)

$t=$ time (5 minutes)

$W=$ welght of enzyme source $\left(\frac{2.5}{100}=0.025 \mathrm{g.}\right)$

\section{(c) Absorption and Calibration Curves}

A solution was prepared containing all the reagents for the determination with the exception of the enzyme-extract and the linoleic acid, having $2.0 \mu \cdot \mathrm{g}$. per $\mathrm{ml}$. of ferric thiocyanate. The absorption of light at different wave lengths was determined with a Coleman Spectrophotometer. As shown in Fig. 1, the maximum absorption was found to occur at $455 \mathrm{millimicron}$.

To make a celibration curve a standard solution of ferric chloride hexahydrate was prepared in a similar mixture of the reagents. (Ferric chloride hexahydrate contains $20.32 \%$ ferric lon.) Many dilutions of the original solution were made to give the desired points on the curve. The colour was developed, as in the procedure above by mixing $5 \mathrm{ml}$. of each dilution with $5 \mathrm{ml}$. of $95 \%$ ethanol and $1 \mathrm{ml}$. of $20 \%$ ammonium thlocyanate. Readings were immediately taken with the Coleman Spectrophotometer set at $455 \mathrm{~m} \cdot \mu$. Fig. 2 shows the ferric ion concentration in gamma per $\mathrm{ml}$. In the reaction mixture. 


\section{Flgure No. 1}

\section{Lipoxidase Determination - Absorption Spectrum of Ferric Thiocyanate}

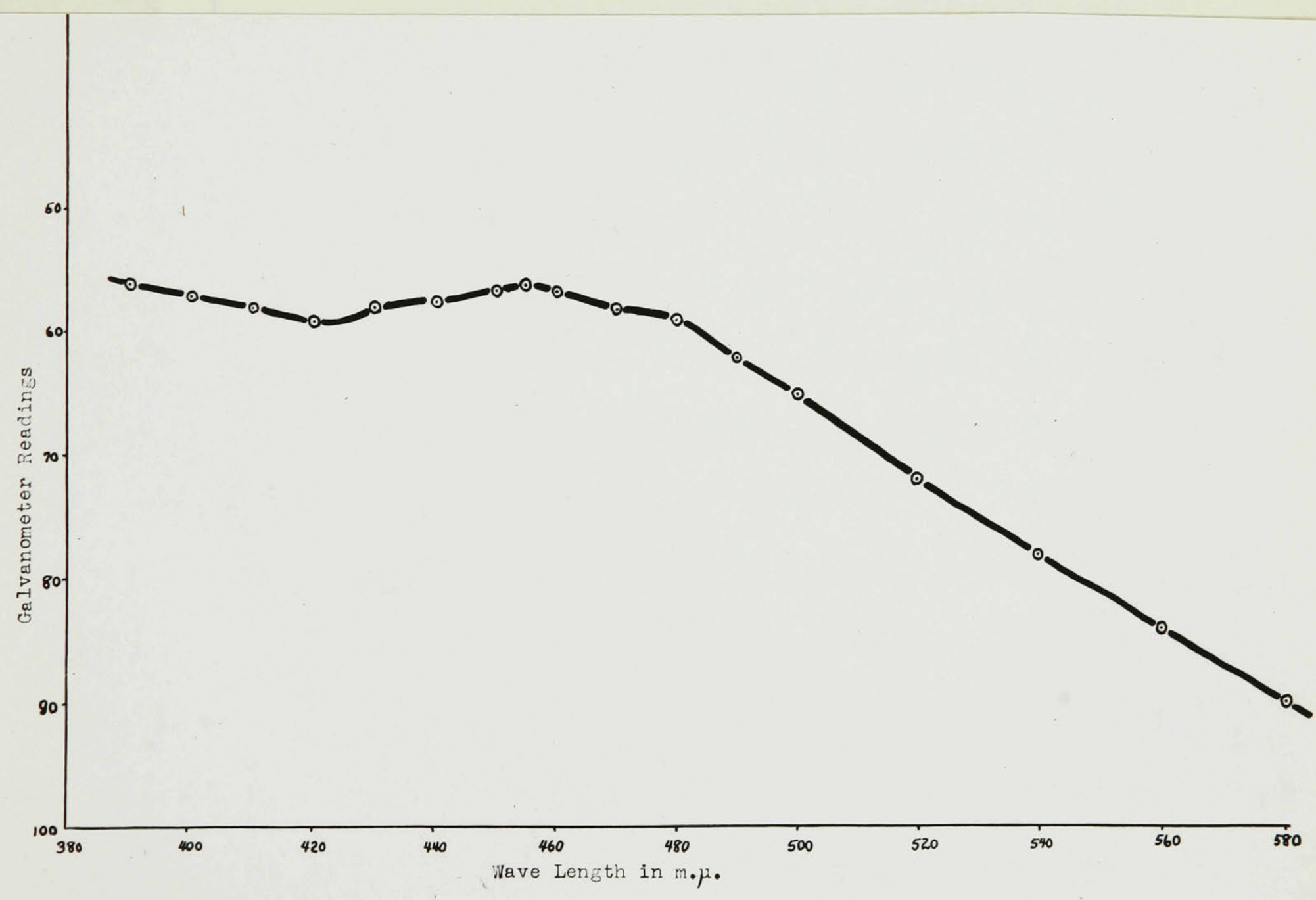




\section{F1gure No.?}

\section{L1poxidase Determination - Calibration Curve}

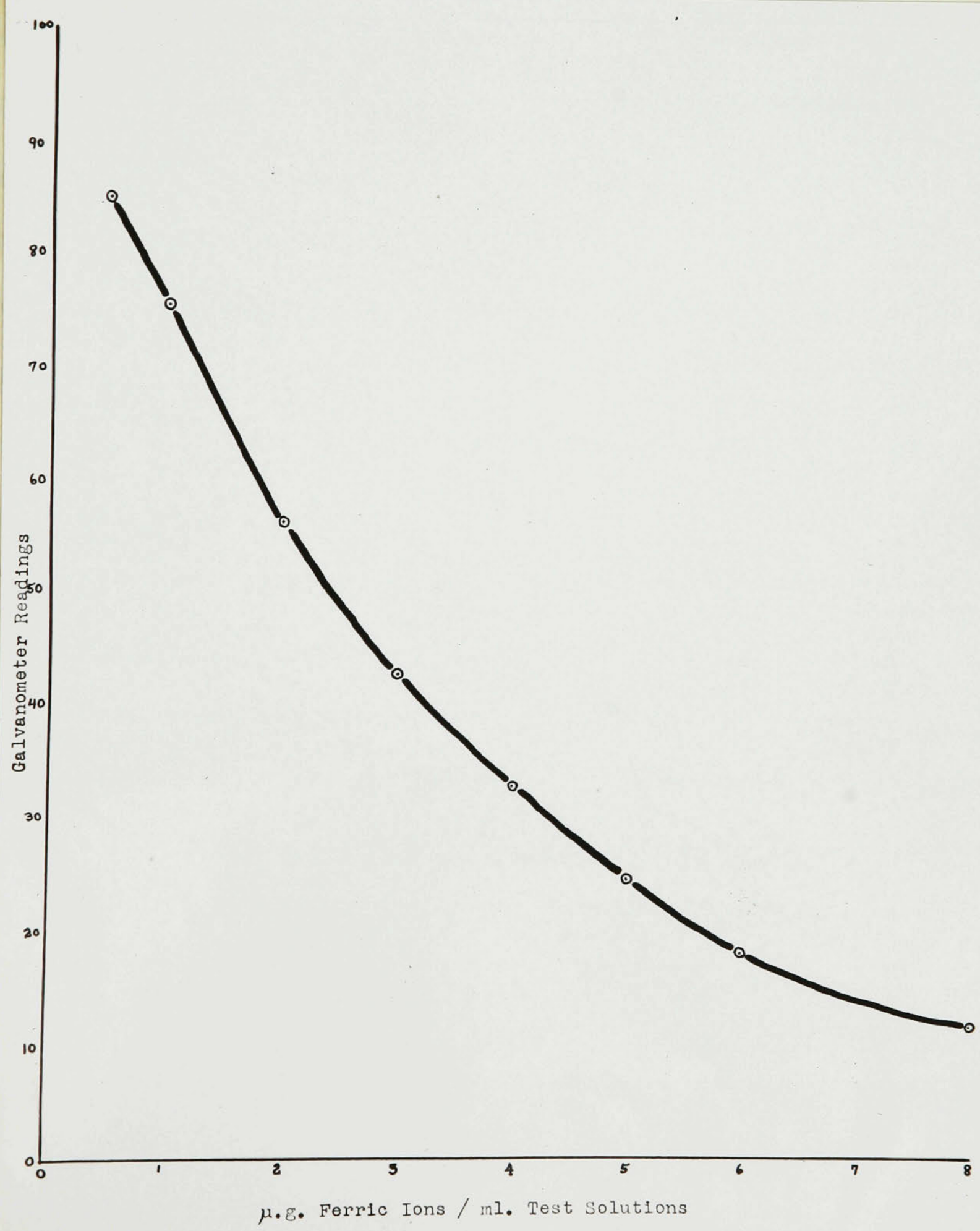


For concentration between 1 and 6 gamma of ferric ion per ml. of reaction mixture, $x=\frac{2-\log G}{\text { gamma } / \mathrm{ml}}=0.1244 \pm 0.0009$, whl ch shows that the curve is logarithmic in form ( $a=$ galvanometer reading).

\section{(d) Study of Conditions for the Determination}

(1) General: Since the calibration curve is logarithmic, the sensitivity of the method decreases at high colour intensities. For this reason no readings were taken at concentrations greater than $4 \mu . g$. of ferric ion per ml. It was also found important to use pure reagents and well washed glassware rinsed in distilled water. As a further precaution the ferric thiocyanate colour was developed under red light; bright daylight and electric light increase the intensity of the colour. Some trouble was also encountered when poor quality linoleic acid was used as it increased the value for the blank. Furthermore, the enzyme concentration and time of reaction had to be adjusted accordingly.

(2) Preparation of enzyme extract: At first the wheat germ was ground in a mortar with acid-washed sand (53) but excessive quantities of Iron remained which gave highly coloured blanks. It was later found that the wheat germ could be ground just as satisfactorily without and. Different concentrations of wheat germ in water were tried to determine the best conditions for extraction and also to give readings in the most sensitive section of the calibration curve. The optimum concentration was 2.5 g. of wheat germ 
in $100 \mathrm{ml}$. of water with 30 minutes shaking. Filtering the extract was compared with centrifuging and it was found that filtering reduced the ilpoxidase content by as much as $50 \%$. The time and speed of centrifuging also had some effect; 2000 revolutions per minute for 10 minutes. gave a clear extract. It w1ll be evident that the detalls of the procedure must be adhered to if comparable results are to be obtained.

(3) Reaction time: Sumer found that the formation of peroxddes was not directly proportional to reaction time, but using a short reaction time and a diluted enzyme extract, the reaction can be considered as being proportional to the enzyme concentration and hence the determinstion is simplified, although in this instance the error is multiplied in calculating the lipoxidase concentration. Taking into consideration (a) the range of accuracy of the calibration curve, (b) maximum values and (c) the straight-line portion of the curve obtained by plotting peroxide formation against time for two samples of wheat germ, the optimum reaction time was found to be 5 minutes.

\section{Determination of Proteolytic Activity}

\section{(a) General}

When confronted by the task of choosing from the literature a method for determining proteolytic actirity applicable in our work, two general types of procedure were found to be arailable. The firgt method uses the material under test as the substrate. Cairn and Balley (2l) made a study 
of eight methods of this type. Denham and Blair (24) and Balls and Hale (2) added two more. These procedures are generally not very sensitive and some are quite cumbersome because they involve a series of amino-nitrogen determinations. The second method employs an artiflclal substrate such as casein, hemoglobin, gelatin, etc. and purified enzyme preparations. Balls et al. (8) and Anson (1) outlined two such methods for determining papain. These methods are generally too long and exacting for routine tests. It $1 \mathrm{~s}$ known that enzymes do not attack different substrates in exactly the same way. In thls study we are interested in the proteoclastic power of the wheat germ enzymes on the protein of the wheat germ 1tself, so we have used the whole wheat germ as the substrate and the source of enzymes, thus avolding the danger of changing the specificity by extraction.

As early as 1903, Vines (74) used the increase in freetyrosine as a measure of proteolytic breakdown and more recently, Anson (1) measured the blue colour given with the phenol reagent and expressed the results in milliequivalents of tyrosine, although realizing that the reaction was not spee clflc, some of the colour belng due to tryptophane, cysteine, etc. This reaction is employed as the basis of our method which is described herewith.

\section{(b) Procedure}

Four 0.250-g. portions of finely ground wheat germ were placed in Erlenmeyer Plasks; to the two control flasks $20 \mathrm{ml}$. 
of a 10\% solution of trichloracetic acid were added and then to all of the flasks $20 \mathrm{ml}$. of cltrate buffer ( $\mathrm{pH} \mathrm{4.5)} \mathrm{and}$ $100 \mathrm{ml}$. of distilled water were added. The buffer was prepared by mixing $70 \mathrm{ml}$. of a solution of citric acld (21.008 8. per l1ter) and sodium hydroxide ( 8 g. per liter) with 30 ml. of 0.1 normal hydrochloric acid. After incubating at $37^{\circ} \mathrm{C}$. for exactly 6 hours, $20 \mathrm{ml}$. of a $10 \%$ solution of trichloracetic acid were also added to the two test flasks and after proper mixing, the solutions were filtered through a Whatman 42 f1lter. One-ml. aliquots of each filtrate were placed in large test tubes, and $20 \mathrm{ml}$. of water, one $\mathrm{ml}$. of 3.85 normal sodium hydroxide and one ml. of "phenol reagent" were added to each. After standing 10 minutes the colour was read in a Coleman Spectrophotometer set at the $650 \mathrm{~m} . \mu$. wave-length.

The sodium hydroxide was used to neutralize the trichloracetic acid, to make the solution alkaline so that the "phenol reagent" reacted with tyrosine and to destroy the excess of reagent. The "phenol reagent" was prepared according to Folin and Clocalteu (30) with lithium sulphate.

The unit of proteolytic activity is expressed as "milliequivalents of tyrosine per kilogram of wheat germ liberated under the test conditions". It was realized that not all the blue colour developed was due to tyrosine, however the colour is expressed in milliequivalents of tyrosine as it was read from the callbration curve. The blank corrected for the pre-existing amino acids and other substances that give a 
blue colour with the "phenol reagent".

The following equation was used to calculate the units of proteolytic activity:

$$
\begin{aligned}
& \frac{(T-B) \times V}{x W}=(T-B) \times 3.1 \text { un1ts/k1logram of wheat germ } \\
& T=\text { concentration of tyrosine in test solution in gamma per ml. } \\
& \text { B " " " "blank " " " } \\
& V=\text { volume of solution in } \mathrm{ml} \text {. (140ml.) } \\
& W \text { :weight of sample in } \mathrm{g} .(0.250 \mathrm{g.}) \\
& \theta \text { sequivalent weight of tyrosine ( } 181 \mathrm{~g} \cdot \text { ) }
\end{aligned}
$$

\section{(c) Absorption Spectrum and Calibration Curves}

In Fig. 3 the galvanometer readings are plotted against wave lengths for a tyrosine solution containing $34 \mu \cdot g$. per ml. The colour was developed in exactly the same way as described for the test. Maximum absorption occurs at a wavelength bejond the useful range of a coleman Spectrophotometer so it was declded to use the $650 \mathrm{~m} . \mu$. wave-length.

The calibration curve (Fig. 4) was obtained with different dilutions of a standard solution prepared by dissolving $100 \mathrm{mg}$. of (Eastman Kodak) tyrosine in $200 \mathrm{ml}$. of a mixture of 5 parts of distilled water; 1 part of a 10\% solution of trichloracetic acid and 1 part of citrate buffer (pH 4.5). The curve obtained is not logarithmic although Folin and ciocalteu (30) obtained a logarithmic curve under certain specific conditions using a large excess of "phenol reagent". Fig. 4 shows that the most sensitive reading were obtained, and hence the optimum conditions for the test, at 
Figure No. 3

Determination of Proteolytic Activity - Absorption Spectrum of the Blue Colour

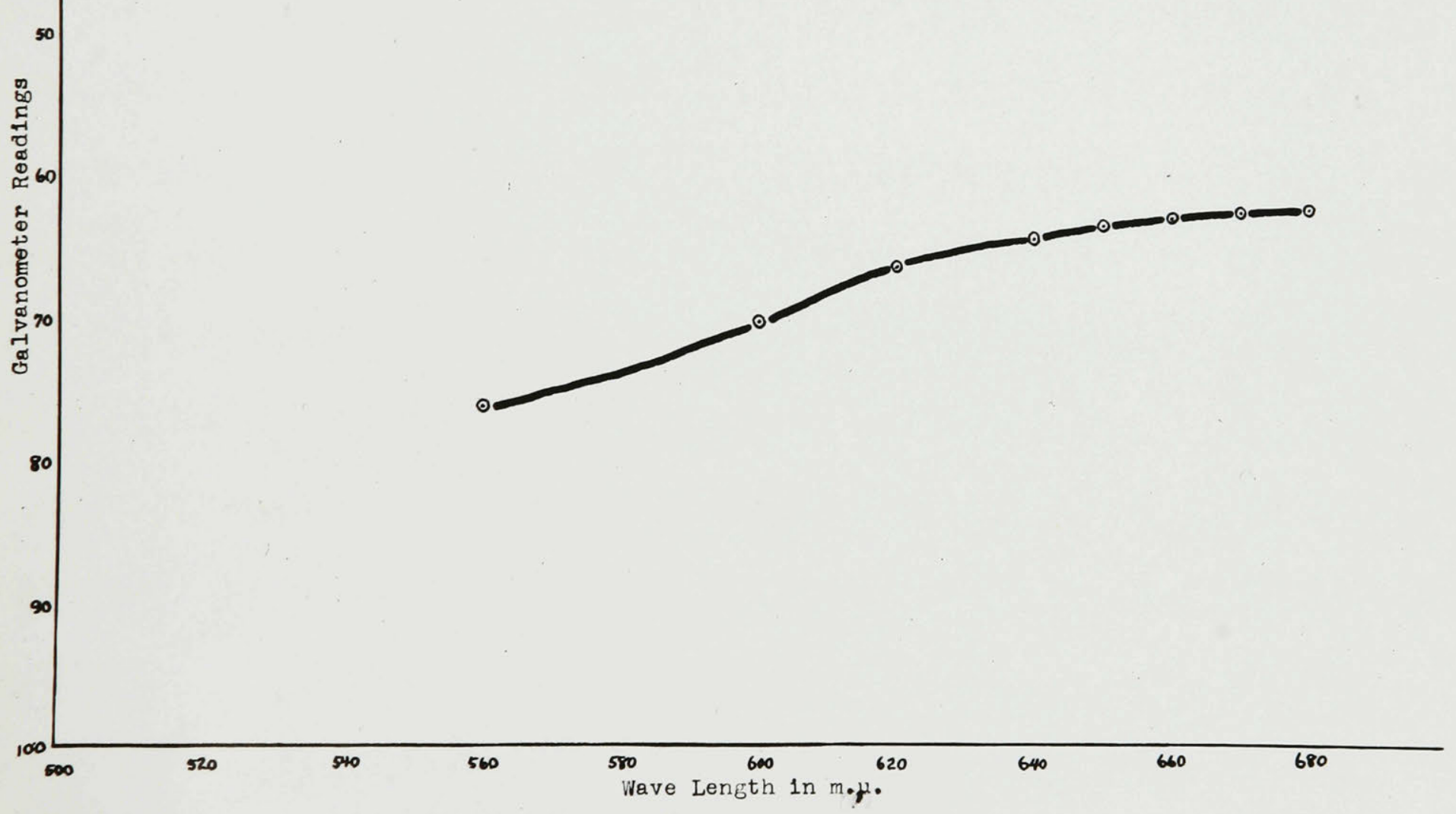


Figure No. 4

Determination of Proteolytic Activity -

\section{Calibration Curve}

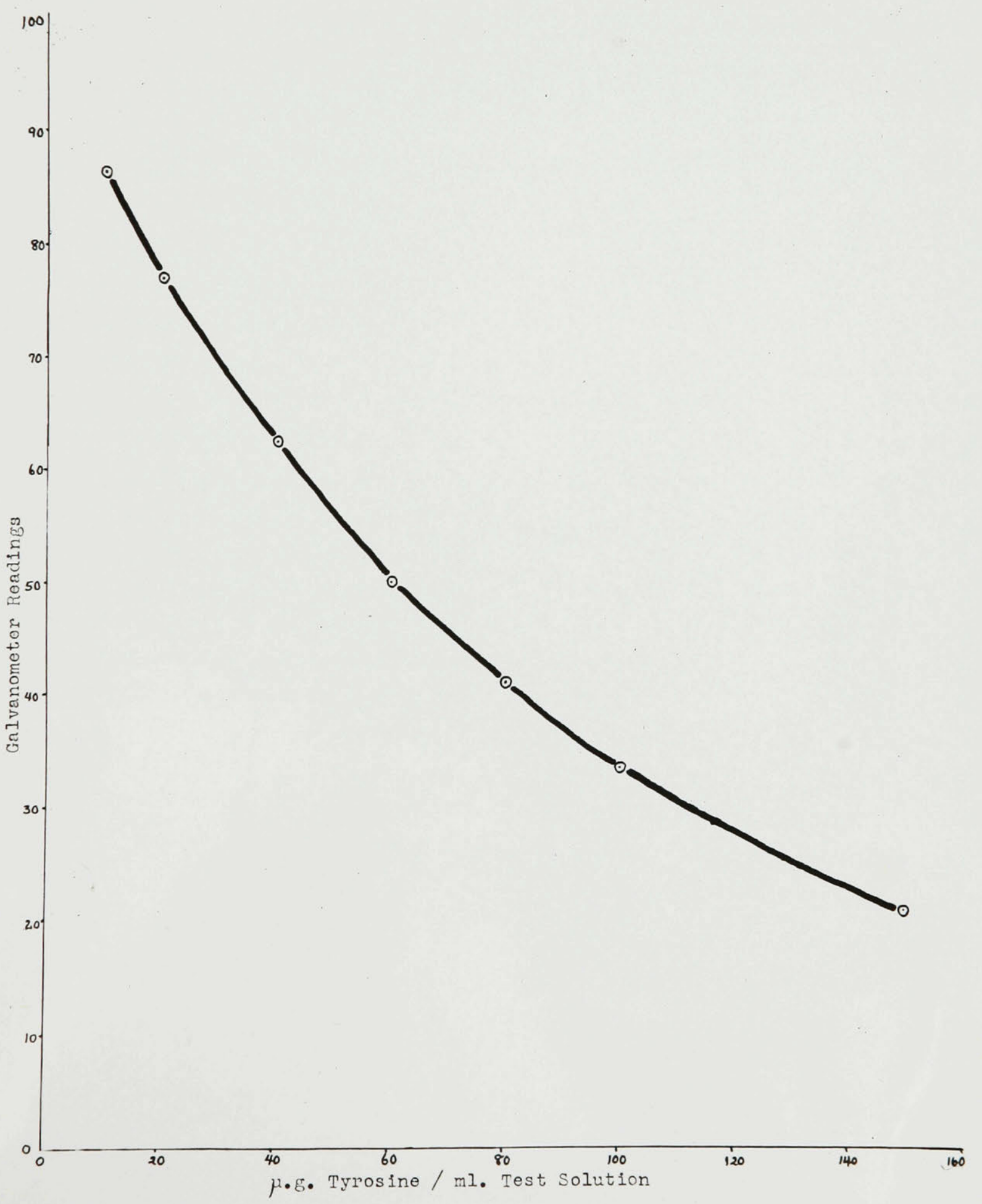


concentrations between 10 and $80 \mu \cdot g$. per ml.

(d) Study of Conditions for the Determination

(1) Sample size; The optimum conditions are those which give the maximum proteolytic activity per unit of wheat germ. From preliminary tests it was found that less than $0.2 \mathrm{~g}$. or more than $0.5 \mathrm{~g}$. of wheat germ in 140-ml. of digestion mixture gave readings beyond the limits of the accurate range of the calibration curve. Finally a series of experiments were conducted to establish the optimum concentrations within the range given above. Some typical results are shown in Table I.

\section{Table I}

Proteolytic Activity with Varying Amounts of Wheat Germ

\begin{tabular}{|c|c|c|c|c|}
\hline \multirow{2}{*}{$\begin{array}{l}\text { Welght } \\
\text { of } \\
\text { Sample } \\
(g \cdot)\end{array}$} & & rotec & $\begin{array}{l}\text { c Act } \\
\% A c \\
0.25 \\
0.25\end{array}$ & $\begin{array}{l}\text { yof } \\
\text { mple }\end{array}$ \\
\hline & $\overline{\mathrm{pH} 4}$ & $\mathrm{pH} 5$ & $\overline{\mathrm{pH} 4}$ & pH5 \\
\hline 0.200 & 29 & 19 & 91 & 83 \\
\hline 0.250 & 32 & 23 & 100 & 100 \\
\hline 0.300 & 27 & 23 & 85 & 99 \\
\hline 0.400 & 22 & 20 & 68 & 87 \\
\hline 0.500 & 13 & 8 & 40 & 35 \\
\hline 1.000 & 8 & 6 & 25 & 29 \\
\hline
\end{tabular}


From Table I 1t can be deduced that 0.25 g. 1s the most satisfactory welght of wheat germ. The results in columns 4 and 5 indicate that at the higher $\mathrm{pH}$ the decrease in proteolytic activity for a given increase in concentration is not as great as at the lower pH. This may be due to the greater solubility of the protein at the higher $\mathrm{pH}$.

(2) pH: Since it is well established that the enzyme of wheat germ is of the papain type, $\mathrm{pH}^{\prime} \mathrm{s}$ between 3.5 and 6 were tried in a series of three experiments with the results shown in Table II.

Table II

Proteolytic Activity at Various $\mathrm{pH}$ 's

Proteolytic Activity

$\mathrm{pH}$

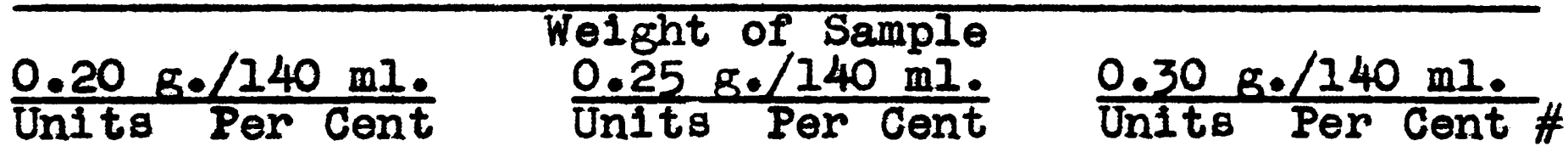

\begin{tabular}{rrrrrrr}
\hline 3.5 & 27 & 72 & 29 & 78 & 26 & 82 \\
4.0 & 29 & 83 & 32 & 86 & 27 & 87 \\
4.5 & 35 & 100 & 37 & 100 & 31 & 100 \\
5.0 & 19 & 55 & 23 & 63 & 23 & 75 \\
6.0 & - & - & 19 & 51 & - & - \\
\hline
\end{tabular}

\# taking pH 4.5 as 100 per cent.

From Table II it is quite clear that $\mathrm{pH} 4.5$ is the optimum for digestion.

(3) Temperature: The initial determinations were carried 
out in a small oven, heated by two 25-watts bulbs and the temperature was controlled at $40^{\circ} \mathrm{C}$. by a DeKhotinsky Thermoregulator. When the lamps were on, the flasks were 1lluminated and therefore, to determine the effect of 11ght, later incubations were carried out in a dark incubator-room at $37^{\circ} \mathrm{C}$. The results obtained under the two conditions are given in Table III.

\section{Table III}

The Effect of Temperature on Digestion in Light and Dark

\begin{tabular}{cccc}
$\begin{array}{c}\text { Weight } \\
\text { of } \\
\begin{array}{c}\text { Sample } \\
(8 .)\end{array}\end{array}$ & $\begin{array}{c}\text { Units of Proteolytic Activity } \\
\text { Oven } \\
\left(40^{\circ} \mathrm{C} .\right)\end{array}$ & $\begin{array}{c}\text { Incubation Room } \\
\left(37^{\circ} \mathrm{C} .\right)\end{array}$ & Per cent \# \\
\hline 0.50 & 18 & 13 & 72 \\
0.40 & 28 & 22 & 77 \\
0.30 & 33 & 27 & 84 \\
0.25 & 38 & 32 & 84 \\
0.20 & 35 & 29 & 84
\end{tabular}

\# activity in incubation room as per cent of activity in copper oven.

The results in column four of Table II show that the activity in the incubation room at $37^{\circ} \mathrm{C}$. was only $84 \%$ of the activity in the oven at $40^{\circ} \mathrm{C}$.

(4) Time: The optimum digestion time was then determinod In a series of experiments with $0.25-8$. samples at $\mathrm{pH} 4.5$. A typical series of results on two samples of different proteolytic activity is shown in Table IV. A digestion time of 
6 hours gives the most consistent results and the maximum activity within the range of greatest sensitivity of the calibration curve and thereforedsconvenient for daily routine analysis.

\section{Table IV}

The Effect of Incubation Time on Prozeolytic Activity

\begin{tabular}{ccc}
\hline $\begin{array}{c}\text { Time } \\
\text { In } \\
\text { Hours }\end{array}$ & \multicolumn{2}{c}{ Units of Proteolytic Activity } \\
\cline { 2 - 3 } Sample "A" & Sample "B" \\
\hline 2 & 24 & 16 \\
4 & 28 & 22 \\
6 & 31 & 23 \\
8 & 30 & 20 \\
10 & 27 & 17 \\
\hline
\end{tabular}

(5) Activators: It was thought that activators such as glutathione and sodium cyanide might reduce the digestion time and Increase the sensitivity of the method. Results are given in Table $v$ for a number of experiments with one sample of wheat germ. 


\section{Table V}

The Iffect of Activators on Proteolytic Activity

Act1vator

Units of Proteolytic Activity

None (control)

$0.5 \mathrm{mg}$. Qlutathione

$1 \mathrm{mg}$.

11

$0.25 \mathrm{mg} \cdot$ Sodium Cyanide
31

31

31

28

Apparently wheat germ already contained an optimum amount of natural activators. The slightly reduced activity in the presence of cyanide might indicate some effect of heavy metals or enzymes containing heavy metals. Thls failure to obtain activation was not important since our main interest was in the naturally occurring proteolytic activity of wheat germ.

\section{Fat-Peroxide Determination}

The method of Chapman and McFarlane (22) developed in this laboratory for the determination of fat-peroxides in milk powders was followed and was found both useful and accurate. It 18 an adaptation of Yule and W1lson's method for gasoline and 1s based on the oxidation of ferrous to ferric iron by the peroxides present and the colorimetric determination of the ferric iron as ferric thiocyanate (80). The same weight of sample and dilutions as for milk porders were used successfully with only minor changes such 
as decanting the reagent instead of filtering after standing two hours in the dark; preparing the blank with $9 \mathrm{ml}$. of reagent and $1 \mathrm{ml}$. of the same acetone as was used to extract the wheat germ; and freshly redistiling the acetone before use. The results of duplicate determinations agreed closeIy and generally fresh wheat germ gave negative peroxd de values. This can be explained by the presence in wheat germ oll of some reducing substances, e.g. the tocopherols.

\section{Storage Tests}

One of the objectives of this investigation was to produce from wheat germ, a cereal of good keeping quality as determined by storage test. The wheat germ was supplied by Ogilvie Flour Mills Company Limited, Montreal, and was obtained from hard winter wheat by a dry milling process ( $11 \%$ molsture), which gave a yield of 0.25 to $0.50 \%$. The purity of this wheat germ is very high - about $95 \%$.

In this storage trial untreated controls were included together with the treated samples to discount the variability in the samples and conditions of storage. Four types of packing materials were used:

(a) "Perfect Seal" sealers.

(b) Läminated metal-foll packing envelopes - Reynolds Metäl Company, Richmond, Virginia.

(c) Wax-coated and wax-and-resin-coated cellophane envelopes - Cellophane Division, Canadian Industries Limited, Montreal. 
The metal-foll and the cellophane envelopes are sealed, air-tight with a warm iron. When moderately filled with carbon dioxide, the wax-and-resin-coated cellophane envelopes were slightly permeable to the gas and in about two days a vacuum existed inside, so that the two walls held together. Air-packing and gas-packing were compared, the inert gas being either nitrogen or carbon dioxide. Gas-packing was performed by almost completely sealing the envelopes but leaving a small opening to introduce a flattened cannula through which the vacuum was applied or the gas admitted. Evacuating and gas-filling were repeated three or four times before the small opening was sealed.

Most of the storage tests were made at $37^{\circ} \mathrm{C}$. because this temperature represented the highest probable shipping temperature but occasionally accelerated tests were carried out at $55^{\circ} \mathrm{C}$. Light was excluded because of its known effect on the stablilty of the samples. The value of these tests may be questioned because these were not normal conditions of storage and new factors, effecting the stability of the product, may have been introduced.

It is well-known that molsture has a great influence on the keeping qualities of cereals so it was decided to control the moisture content of each series of treated samples - it was generally kept below 5\%.

Two methodswere used to test the quality of the stored product. Peroxide values were determined and a small panel of judges accessed the flavour and odour of the products. 
After experience to develop a sense of taste and smell, the decisions of the panel were generaily unanimous. It will be shown, in the experimental part of this thesis, that the peroxide-values were not highly correlated with other criteria of quality.

\section{Baking Teatg}

Baking tests were the final criteria of the quality of wheat germ to fortify bread. These tests were carried out in the experimental baking laboratory of the Ogilvie Flour Mills Company Limited, Montreal. In the baking tests the Ingredients used were: $380 \mathrm{~g}$. "Buffalo" flour, $19 \mathrm{~g}$. wheat germ, $11.4 \mathrm{~g}$. yeast, $11.4 \mathrm{~g}$. sugar, $6.6 \mathrm{~g}$. salt and $200 \mathrm{ml}$. of water. The yeast was dissolved in $100 \mathrm{ml}$. of water and the salt and sugar were dissolved in the remainder of the water. All of the ingredients were mixed in a Hobart Mixer, fltted with a cake paddle, and it was run for half a minute In low gear and a minute and a half in second gear.

Loaf volume, crumb colour, texture and comments on the handling qualities were recorded. 


\section{The Preparation of a Cereal Food}

\section{(a) Genoral}

The problems involved in the preparation of a cereal food from wheat germ are mainly to improve 1ts palatability and Its keeping qualities. Light tossting is said to Improve the palatability of wheat germ. Improved keeping quallties might be expected from elther gas-packing to prevent oxidation during storage, or a treatment which destroyed the harmful substances naturaliy present, or a combination of the two. Ges-packing 18 an expensive process and probably not effective with raw wheat germ but may improve the keeping quality of treated wheat germ. The inactivation or destruction of the enzymes in wheat germ is chlefly a problem of controlling the oxidation or denaturation of the protein without affecting the quality of the product.

Toasting destroys the characterlstic and pleasing flavour and odour of fresh wheat germ but has a beneflcial effect on the stability of the product. This suggested that the degree of oxidation and denaturation of the protein required to give a stable product might be obtained, without adversely affecting the flavour and odour, by a less drastic heat treatment under controlled conditions especially in regard to the moisture content. The development of such a process is described in the following sections.

\section{(b) First Trials}

Two portions of wheat germ were placed in an oven at 
95 - $105^{\circ} \mathrm{C}$. for 12 hours: one in an open container and the other in a closed flask filled with nitrogen. The wheat germ in the open container was dry and of pleasant appearance, smell and taste. The other was brown in colour and unpleasant in flavour. A lipoxidase determination on both samples showed that the enzyme was completely inactivated. The proteolytic enzymes were only destroyed in the closed vessel, thus indicating the importance of moist heat, however the obvious defects in the flavour and colour of this sample had to be overcome. Finally it was found that heating for $1.5 \mathrm{hr}$. at $100^{\circ} \mathrm{C}$. In a closed vessel under nitrogen destroyed the Ilpoxidase and the proteolytic enzymes and the brown discolouration did not develop... To evaluate the keeping quality of these products, peroxide values were determined after a short two weeks storage at $5^{\circ} \mathrm{C}$. and at room temperature. Some typical results are given in Table VI which indicates that heating for $1.5 \mathrm{hr}$. under nitrogen did not increase the peroxide content.

\section{Table VI}

Peroxide Content of Treated Wheat Germ

Sample $\frac{\text { Peroxtdes }- \text { m.e./ } / \mathrm{K}_{\text {g. }} \text {. wheat germ }}{\left(5 \mathrm{C}_{0}\right)}$

Control (untreated)

n11

trace

Heated $12 \mathrm{hr}$. at $100^{\circ} \mathrm{C}$. (open container)

2.2

Heated $1.5 \mathrm{hr}$. at $1000 \mathrm{C}$. (closed container) 
Following these preliminary trials, a more comprehensive Storage Test (No.l) was undertaken as outlined in Table VII.

\section{Table VII}

Analysis of Samples before Storage Test No. 1

\begin{tabular}{|c|c|c|c|c|c|}
\hline \multirow[b]{2}{*}{$\begin{array}{l}\text { Sample } \\
\text { Kumber }\end{array}$} & \multirow[b]{2}{*}{ Treatment } & \multirow[b]{2}{*}{$\begin{array}{l}\text { Storage } \\
\text { Condition }\end{array}$} & \multicolumn{2}{|c|}{ Sample Before } & \multirow{2}{*}{$\begin{array}{l}\text { Storage } \\
\text { Proteolytic } \\
\text { Activity } \\
\text { (Units/. }\end{array}$} \\
\hline & & & $\begin{array}{l}\text { Molsture } \\
\text { (per cent) }\end{array}$ & $\begin{array}{l}\text { Iipacidase } \\
\text { (Units//Rg.) }\end{array}$ & \\
\hline 1 & $\begin{array}{l}\text { Control } \\
\text { Untreated }\end{array}$ & air & 11.1 & 537 & 42 \\
\hline 2 & $\begin{array}{l}\text { Control } \\
\text { Untreated }\end{array}$ & nitrogen & 11.1 & 537 & 42 \\
\hline 3 & $\begin{array}{l}1.5 \mathrm{hr},-100^{\circ} \mathrm{C} \\
\text { in a1r, c10sed } \\
\text { system }\end{array}$ & - air & $10 \cdot 3$ & nil & n11 \\
\hline 4 & $\begin{array}{l}1.5 \mathrm{hr},-100^{\circ} \mathrm{C} \\
\text { in air, c108ed } \\
\text { system }\end{array}$ & nitrogen & 9.6 & $\|$ & 20 \\
\hline 5 & $\begin{array}{l}1.5 \text { hr. }-100^{\circ} \mathrm{C} \\
\text { in nitrogen, } \\
\text { closed system }\end{array}$ & air & 8.6 & $" 1$ & 23 \\
\hline 6 & $\begin{array}{l}1.5 \text { hre } 100^{\circ} \mathrm{C} \\
\text { in nitrogen, } \\
\text { closed system }\end{array}$ & nitrogen & 9.7 & " & 16 \\
\hline 7 & $\begin{array}{l}\text { I2 hr. }-100^{\circ} \mathrm{C} \text {. } \\
\text { in air, open } \\
\text { sjstem }\end{array}$ & $\operatorname{air}$ & 0.9 & $\|$ & 35 \\
\hline 8 & $\begin{array}{l}12 \mathrm{hr} \cdot-100^{\circ} \mathrm{C} . \\
\text { in a1r, open } \\
\text { system }\end{array}$ & nitrogen & 0.9 & " & 35 \\
\hline
\end{tabular}

Ten samples from each of the elght treatments were packed in laminated metal-foll envelopes, sealed and stored at $37^{\circ} \mathrm{C}$. The test was discontinued after 5 weeks beceuse even at the 
end of two weeks all the samples had developed atrong offflavours and at the end of five weeks : the required information had been obtained. The proteolytic activity of all the treated samples was reduced and it was most marked in those samples with the highest moisture content, thus indicating the Importance of the presence of molsture during heating. The lipoxidase enzymes were destroyed in all the treated samples, but there is little or no relationship between Iipoxidase activity and peroxide formation (Table VIII) since the control samples, with the enzymes active, showed a smallor increase in peroxides than samples in which the enzymes had been destrojed.

\section{Table VIII}

Peroxide Content after Varying Periods of Storage-Test No. 1

Samplo

Number Treatment
Peroxides $-m_{\cdot e \cdot} / \mathrm{K}_{\mathrm{B}}$. Storage-Before 1 week 3 weeks 5 weeks
1 Control Untreated

2 Control Untreated

$3 \quad 1.5 \mathrm{hr} \cdot-100^{\circ} \mathrm{C}$. In air, closed system

$4 \quad 1.5 \mathrm{hr} .-100^{\circ} \mathrm{C}$. in nitrogen, closed system

$5 \quad 1.5 \mathrm{hr} .-100^{\circ} \mathrm{C} .1 \mathrm{n} \mathrm{nitro-}$ gen, closed system

$6 \quad 1.5 \mathrm{hr} \cdot-100^{\circ} \mathrm{C} .1 \mathrm{n}$ nitrogen, closed system

$712 \mathrm{hr} \cdot-100^{\circ} \mathrm{C}$. in air, open system

$812 \mathrm{hr} \cdot-100^{\circ} \mathrm{C}$. in air, open system

\begin{tabular}{|c|c|c|c|}
\hline n11 & nII & 0.4 & 16.0 \\
\hline " & $"$ & 0.3 & 14.3 \\
\hline " & 0.2 & 1.2 & 20.3 \\
\hline$"$ & 0.1 & 1.5 & 23.4 \\
\hline "I & n11 & 0.9 & 10.0 \\
\hline 11 & " & nil & $5 \cdot 3$ \\
\hline 1.0 & 20.7 & 39.0 & 43.0 \\
\hline 1.0 & 10.1 & 54.7 & 60.0 \\
\hline
\end{tabular}


Rancldity in wheat germ is apparent by smell and taste when the peroxide-value has increased to about $20 \mathrm{~m} \cdot \theta_{0} / \mathrm{K}_{\mathrm{g}}$. Offflavours were least pronounced in sample 7 and 8 , thus indicating that the peroxide value was not a good criterion of the keoping quality and apparently the fat does not contribute to these off-flavours. The results in Table VIII also show that:-

(a) heating under nitrogen was less. oonducive to oxidation than heating in air (compare treatments 3 and 4 with 5 and 6);

(b) prolonged heating in air was harmful in so far as peroxide formation was concerned (see treatments 7 and 8);

(c) there was no beneficial effect from nitrogen packing (compare odd with even-numbered treatments).

Samples 7 and 8 definitely developed less off-flavours and these samples had the lowest molsture content, thus indicating that molsture played an important part in the development of off-flavours. Pearce (59) drew attention to the importance of moisture in relation to the keoping quality of the germ and since breakfast cereals usually have a moisture content below 5\% it was decided that, in the next trials, the moisture content of the germ would be kept below this level. It was also suspected that the packaging materials might be defective because, similar samples stored in glass containers at $50^{\circ} \mathrm{C}$. , did not develop the same off-flavours. Furthermore, in a study of enzyme inactivation at different temperatures 
In which the germ was packed in metal-fo1l envelopes, offflavours developed very rapidiy so that the experiment had to be discontinued. When some of these samples were replaced in open containers and dried in an oven, the off-flavours disappeared. It is concluded that the spollage of the germ In these experiments was probably due to the combined influence of the packaging material and the moisture content of the product.

\section{(c) Successive Mo1st and Dry Heat Treatments}

As the presence of moisture was necessary to destroy the enzymes and as a dry sample kept best, a process was developod whereby the sample was first treated w1th molst heat and then with dry heat in the apparatus 1llustrated. The following is a description of a typical and most successful experiment and of the apparatus employed.

About $400 \mathrm{~g}$. of wheat germ were placed in a one-liter, round-bottom flask (A), with a glass-inlet tube (B), reachIng to the bottom of the flask and connected at (c), to a tank of nitrogen. Tube (D), was connected with two calcium chloride traps ( $F$ and $F$ ), an 1ce trap $(G)$, a manometer (H), and a Hivac pump (I). The flask was evacuated and refilled with nitrogen three times, stopcocks (M) and (N) were closed and the bolling water bath (L) placed underneath. After 1.5 $\mathrm{hr}$. of molst heat treatment the stopcocks $(M)$ and $(N)$ were opened and nitrogen passed through gently for $1.5 \mathrm{hr}$. to give the dry heat treatment in an oxygen-free atmosphere. The water bath was removed and the wheat germ cooled by passing the gas through it for another half-hour. During the drying 


\section{Figure No. 5}

\section{Apparatus for the Siccessive Molst and Dry Heat Treatment}

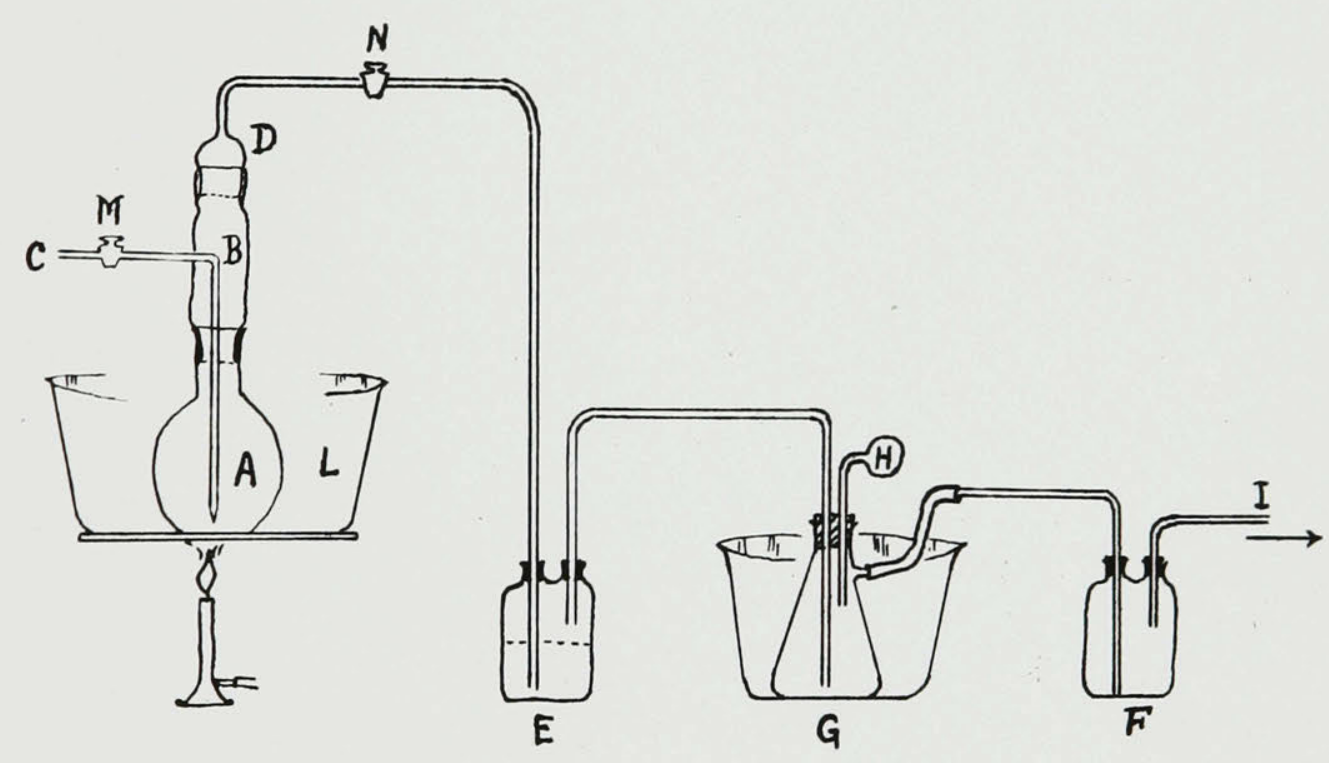


period, the flask was evacuated twice for five minute periods at less than $0.5 \mathrm{~cm}$. of mercury pressure, to remove molsture and other volatile substances.

Numerous experiments were conducted in which the duration of the molst heat and dry heat treatments were varied. In the procedure just described the times given were the minimum required to destroy proteolytic activity and to assure the best keoping quality. Storage Test No. 2 was designed to determine the keeping quality or the product when packed in metal-foll packages and wax-coated cellophane packages, and stored in air or in nitrogen. An accelerated test at $55^{\circ} \mathrm{C}$. was employed. The material packed in metal-foll-lined envelopes apoiled quite rapidly but in cellophane it kept fresh and palatable for at least one month. Lipoxidase enzymes were destroyed even by the short-time heat treatments and it 18 noteworthy that the control sample with the enzyme active did not contain more peroxides than the treated samples (Table IX). 


\section{Table IX}

Peroxide Content of Some Samples from Storage Test No.2 (Samples packed in cellophane envelopes and stored at $55^{\circ} \mathrm{C}$.)

Treatment $\frac{\text { Peroxides }\left(m_{. \theta} \cdot / \mathbb{L}_{g \cdot}\right)}{\text { At start After one month }}$

$1.5 \mathrm{hr} . \mathrm{W}-1.5 \mathrm{hr} \cdot \mathrm{D}-\mathrm{A}$

nil

$1.5 \mathrm{hr} \cdot \mathrm{W}-1.5 \mathrm{hr} \cdot \mathrm{D}-\mathrm{N}$

$1.0 \mathrm{hr} \cdot \mathrm{W}-1.0 \mathrm{hr} \cdot \mathrm{D}-\mathrm{N}$

$1.5 \mathrm{hr} \cdot \mathrm{W}-0.5 \mathrm{hr} \cdot \mathrm{D}-\mathrm{N}$

Control-Untreated n

$\begin{array}{ll}\text { "11 } & 0.7 \\ \text { " } & 1.1 \\ \text { " } & 0.4 \\ \text { " } & 0.2\end{array}$

$W=$ molst heat in a closed container

$D=$ dry heat in an open system

$\Lambda=$ packed in air

$N=$ packed in nitrogen

Off-flavours are not due to peroxides because when these were present the peroxide value was still remarkably low. Packing in nitrogen or in air made little difference in so far as peroxide values were concerned. There is a slight indication that increasing the drying perlod caused the formation of more peroxides.

\section{(d) Solvent Treatments}

Untreated wheat germ is a very unstable food but "Tonik" Wheat Germ keeps very well for a long time. The difference between the two is that the fat has been extracted from "Tonik" Wheat Germ. However the experiments reported above 
have indicated that fat decomposition is not the important factor in the spoilage of the germ. Therefore, the solvent (ethylene dichloride) must have some preserving action on the non-fat constituents of the germ. The effects of a number of different solvents, e.g. ethyl-ether, petrol-ether, chloroform, carbon tetrachloride, ethylene dichloride, methanol and ethanol - were studied in test-tube experiments. All of these solvents destrojed the lipoxidases and with the exception of ethyl and petrol-ether all destroyed the proteolytic activity.

In subsequent experiments, as it was not desired to remove the fat, only the vapours of the varlous solvents were passed through the germ. Using the apparatus shown in Fig.6, the treatments were carried out in the following manner. The wheat germ was placed in the flask (A) which was evacuated and refilled two or three times with nitrogen. The flask was then heated by the water bath $(B)$ at $15-20^{\circ} \mathrm{C}$. above the bolling point of the solvent used. When the desired temperature was reached the solvent was boiled in (c) and its vapoux passed into the wheat germ through the inlet tube (D) and condensed in $(E)$. When the desired volume of solvent had been passed through or the desired amount of time had elapsed a vacuum as applied at $(F)$ or nitrogen or carbondioxide was introduced at $(G)$ to remove the remaining solvent vapours. In some experiments the vacuum and gas treatments were employed alternately and even simultaneously. Storage Teat No. 3 compared the effect of varlous 
F1gure No.6

Apparatus for the Solvent Process




solvents. The samples were packed in metal-foll envelopes, glass sealers and wax-coated cellophane envelopes and stored at $55^{\circ} \mathrm{C}$. Only ethylene dichloride and chloroform improved the keeping qualities, all the other solvents developed some strong off-flavours different from the usual spoilage of wheat germ. In this test it was again observed that there is not much correlation between keeping quality and peroxide and

value,/that an increase in peroxides is not the main cause of spollage. Reynold's metal-foll packages are not sultable for the storage of wheat germ(see Table X).

\section{Table X}

Results of Storage Test No.3 (Two Months Storage at $55^{\circ} \mathrm{C}$ )

\begin{tabular}{|c|c|c|c|c|}
\hline Treatment & $\begin{array}{l}\text { Packed in } \\
\text { phane finve } \\
\text { Peroxides } \\
\left(\mathrm{m} \cdot \mathrm{e}_{\mathrm{g}} / \mathrm{K}_{\mathrm{g}}\right)\end{array}$ & $\begin{array}{l}\text { Del10- } \\
\text { lopes } \\
\text { Remarks }\end{array}$ & $\begin{array}{l}\text { Packed in } \\
\text { Lined } \\
\text { Peroxides } \\
\left(\mathrm{m} \cdot \theta_{\cdot} / \mathrm{K}_{\mathrm{g}} \cdot\right)\end{array}$ & $\begin{array}{l}\text { Metal-Foll- } \\
\text { nvelopes } \\
\text { Remarks }\end{array}$ \\
\hline $\begin{array}{l}\text { Control } \\
\text { Untreated }\end{array}$ & .1 & $\begin{array}{l}\text { slight } \\
\text { off-flavour }\end{array}$ & .2 & $\begin{array}{l}\text { strong } \\
\text { off-flavour }\end{array}$ \\
\hline Combined Heat & $\cdot 3$ & $\begin{array}{l}\text { slight } \\
\text { off-flavour }\end{array}$ & .1 & $\begin{array}{l}\text { strons } \\
\text { off-flavour }\end{array}$ \\
\hline $\begin{array}{l}\text { Fthylene } \\
\text { Dichloride }\end{array}$ & .4 & very good & .6 & fair \\
\hline Chloroform & .4 & $\begin{array}{l}\text { good, taste } \\
\text { of solvent }\end{array}$ & $\cdot 3$ & $\begin{array}{l}\text { fair, taste } \\
\text { of solvent }\end{array}$ \\
\hline
\end{tabular}

Only the treatments which gave the better products are recorded In Table $X$, other solvents gave off-flavours which developed in a very short time.

Fthylene dichloride, or chloroform-treated wheat germ is a dry product, of nice appearance although slightly 
bleached in comparison to the untreated material and of a pleasant nutty flavour. Ethylene dichloride was prefereed because it was already used commercially as a solvent, it was more easily removed and it seemed to give a product of good keeping quality.

An experiment was next carried out to determine the best way to pass ethylene dichloride vapour through the wheat germ. A 400-g. sample of germ was placed in a 500-ml. round bottom flask and the vapour from $250 \mathrm{ml}$. of ethylene dichloride passed through the germ in 30 minutes. The experiment was repeated but with 500,750 and $1,000 \mathrm{ml}$. of solvent passed through the same amount of wheat germ in the same time. The proteolytic activity was destroyed even at the lowest rate at which the solvent was passed through, but the keeping quality was best when the vapours were passed through most rapidiy, probably because of the more complete removal of moisture and of volatile substances responsible for offflavours. A 400-g. sample was treated for one hour with one liter of ethylene dichloride, then carbon dioxide was passed for two hours and finally the flask was evacuated for 2 hours while the material cooled. This sample kept very fresh and appetizing during $3 \frac{1}{2}$ months storage in a sealer at $55^{\circ} \mathrm{C}$.

The difficulty encountered with these treated products was to remove the last trace of odour and especially taste of the solvent. Many different techniques were used but the results were still quite erratic so that the process still required further improvement. 
(e) Solvent and Steam Treatments

The apparatus used was exactly the same as that shown in Fig. 6, and the process was the same as before, but a deodorization period was added in which steam was passed under high vacuum (Iess than $0.5 \mathrm{~cm}$. of mercury). After the different factors influencing the treatment had been studied, the following procedure was developed. A 250-g. sample of wheat germ was placed in the flask and heated to $100^{\circ} \mathrm{C}$. In 20 minutes and 600-g. of ethylene dichloride passed through in 1.5 hours. Then the flask containing the ethylene dichloride was replaced by one containing water at room temperature and a high vacuum was applied for one hour to the system while the wheat germ in the flask was held at $100^{\circ} \mathrm{C}$. The flask was cooled, (C) closed to stop water vapour enterIng and the vacuum was maintained. The product had excellont palatibility, low moisture content and no proteolytic activity. The product was subjected to a storage Test (No.4) as described in Table XI, using the cellophane envelopes and storing at $37^{\circ} \mathrm{C}$. 
Table XI

Storage Test No. 4 on Solvent and Steam Treated Product

\begin{tabular}{|c|c|c|c|c|c|}
\hline $\begin{array}{l}\text { Sample } \\
\text { Number }\end{array}$ & Treatment & $\begin{array}{l}\text { Pack- } \\
\text { Ing } \\
\text { Atmo- } \\
\text { sphere }\end{array}$ & $\begin{array}{l}\text { Freshly Tre } \\
\text { Moisture } \\
\text { (per cent) }\end{array}$ & $\begin{array}{l}\text { ated Semples } \\
\text { Proteolytic } \\
\text { Activity } \\
\text { (units } / \mathrm{Kg}_{\mathrm{g}} \text { ) }\end{array}$ & $\begin{array}{l}\text { Time } \\
\text { Products } \\
\text { Remalned } \\
\text { Palatable } \\
\end{array}$ \\
\hline$I$ & untreated & $\mathrm{CO}_{2}$ & 6.2 & 31 & 1 month \\
\hline II & untreated & air & 6.2 & 31 & 1 month \\
\hline III & solvent - steam & $\mathrm{CO}_{2}$ & $4 \cdot 7$ & 6.2 & $\begin{array}{l}\text { over } 8 \\
\text { months }\end{array}$ \\
\hline IV & steam only & $\mathrm{CO}_{2}$ & 5.0 & n11 & $\begin{array}{l}\text { over } 8 \\
\text { months }\end{array}$ \\
\hline
\end{tabular}

One sample was treated with steam only. The steam was first passed rapidly through the germ just as when treating with ethylene dichloride and then passed slowly as in deodorizing. This was done to check on the effect of ethylene dichloride and it was found that steam alone is effective. This explains the results of earlier experiments in which the enzymes were inactivated by heating the moist germ in a closed system. These samples were still of good quality after elght months storage but there was not enough of the sample to continue the test beyond this time. Of the untreated samples the ones stored in air seemed to keep better than the ones in carbon dioxide. The packing materials used were the special resin-and-wax-coated cellophane enveloped. These tests had shown that a highly desirable cereal food could be produced which had excellent keeping quality and a fresh pleasant taste. 
(f) The Use of a New Equipment for the Treatment of Wheat Germ

The principal objections to the process described above were that it was expensive since it required an all-glass apparatus, including a vacuum pump, and it was difficult to get a uniformly treated product. It was thought that by agitating the sample at temperature slightly above the bollIng point of water, the procedure would be more readily adaptable to commercial development. Taking these points Into consideration, the apparatus shown in Fig. 7 was designed and assembled. Steam or solvent vapours were generated in a distilling flask (A), fitted with a safety valve. The side arm was connected to a T-tube having an inlet for gas (B) on one side and on the other a glass-tube coll (C), the latter being immersed in a thermostably controllod oil bath (D). The super-heated vapours were admitted through a hollow shaft (I) into the chamber which contained the wheat germ and escaped through a number of perforations in the shaft. The escaping vapours were removed through the hollow shaft $(F)$ and were condensed in $(G)$. The chamber was screwed on the shaft $(E)$ by which it was supported and rotated. The motor and the pulley which rotated the shaft were so arranged as to give 30 to 60 revolutions per minute. The chamber, $15.5 \mathrm{~cm}$. Iong with a diameter of $12.5 \mathrm{~cm}$., was made of a solid block of bronze with a screwed-in cover, and was coated on the inside with a plastic "Iithcote". This coating was found to withstand the treatment. The chamber was surrounded by a steam jacket by which the germ was heated to $110-115^{\circ} \mathrm{C}$. The 


\section{Figure No. 7}

Equipment for the Treatment of Wheat Germ
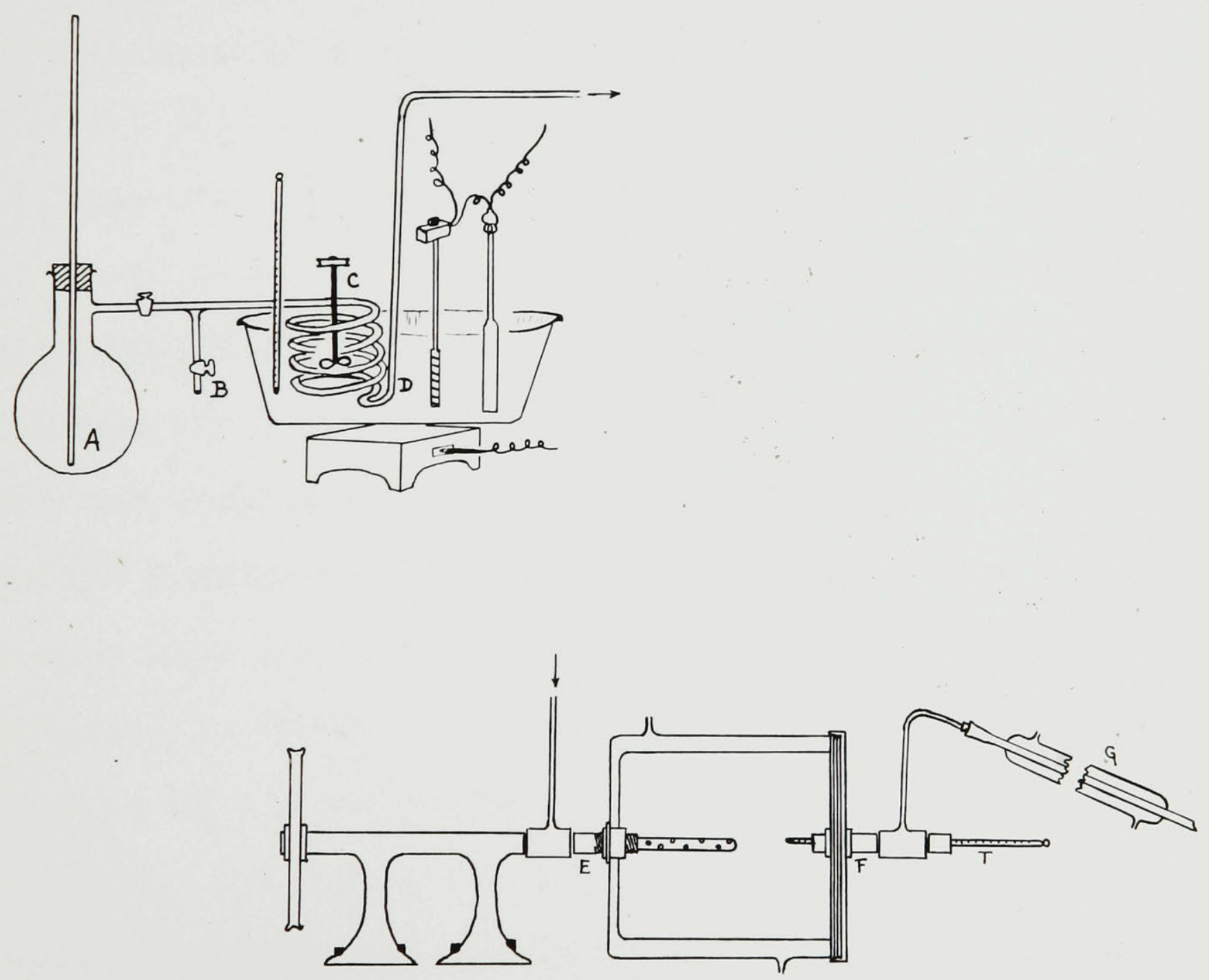
temperature being read on the thermometer (T).

A large number of palatable and pleasant flavoured samples of wheat germ were prepared with this apparatus by treating with steam or ethylene dichloride or both. Sometimes sodium chloride was added to the germ with a further improvement in the taste, the best product being obtained with 2\% salt. A typical processing was carried out as follows:- $200 \mathrm{~g}$. of wheat germ were placed in the chamber, the 011 bath was maintained at $117^{\circ} \mathrm{C}$., the temperature in the chamber rose to $97^{\circ} \mathrm{C}$. In 10 minutes when the steam treatment was started. The steam filled the chamber in two minutes and the temperature inside reached $110^{\circ} \mathrm{C}$. After 30 minutes of steam treatment at $110^{\circ} \mathrm{C}$., nitrogen was passed through for 40 minutes while the chamber was kept above $100^{\circ} \mathrm{C}$. The chamber was then cooled to room temperature in 7 minutes by passing cold water through the steam jacket. Under these conditions the proteolytic activity was destroyed and a dry product was obtained. Storage Test No. 5 was made on some typical samples prepared with this equipment. The samples were alr-packed in wax-coated cellophane envelopes and stored at $37^{\circ} \mathrm{C}$. One sample of ethylene dichloride-treated and steam-deodorized germ kept w1thout spollage for three months but, in general, the samples did not keep as well as the previous ones prepared in the all-glass apparatus. The addition of salt actually reduced the keeping quality of the cereal and it was more difficult to remove the moisture from these samples. Some heary metal contamination might have 
occurred as there was some uncovered metal at the points where the chamber was screwed onto the shafts $(r)$ and $(F)$. The high racuum and the careful flushing with nitrogen before heating may also have been important factors in producing the better products by the previous treatment. A further objection to this apparatus was the difficulty experienced in reducing the moisture content of some samples to a low enough level. Probably only an alr-tight machine with a Hivac pump could duplicate the excellent results obtalned in the all-glass apparatus. However, since these products were st1ll good after storage in air for three months at $37^{\circ} \mathrm{C}$, there is a possibility that the process might be developed industrially.

\section{The Use of Treated Wheat Germ in Baking}

\section{(a) General}

If we are to decrease the consumption of foods of antmal origin, since they are uneconomically produced and their use decreases the number of people that can be fed per acre, we must find a way of introducing into our diet more vegetable foods which contain more and better protein with a good supply of the vitamin B-Complex. Wheat germ would be a good source of these factors, but how are we going to utilize large quantities of it as human foods We daily consume large amounts of white flour in bread and some in biscults and the obvious course is to restore to them the wheat germ without damaging their taste and appearance. It was thought 
that the destruction of the enzymes would be a step towards the solution of this problem, particularly in the baking of bread which is so markody influenced by the enzyme systems. Furthermore, the treatment also removes the "raw" taste of wheat germ, whlch to some people 1s quite unpleasent.

\section{(b) Biscuit Baking}

Some of the better-flavoured samples of wheat germ prepared with the new equipment were used in baking tea biscuits. A number of amples of tea biscuits containing different levels of treated wheat germ and control samples without germ, with untreated germ and with "Tonik" Wheat Germ, were prepared. The appearance of the biscuits baked with flour containing treated wheat germ was as good or even better than that of the biscuits prepared from flour alone. The taste of the biscuits was improved by the addition of treated wheat germ more than by the addition of "Tonik" Wheat Germ (probably the fat present improved the palatability). Untreated wheat germ imparted some of its "raw" taste to the biscults. As much as $20 \%$ of treated wheat germ was tried with very good results; however at this level the biscuits were slightly "heavy". This difficulty was not encountered at the $10 \%$ level.

\section{(c) Bread Baking}

$\Delta$ preliminary bread-baking test was run on two samples, one ethylene dichloride and steam-treated and the other only steam-treated. The enzymes were completely destroyed in 
both and the bread obtained was excellent. A series of samples was then specially prepared in the new apparatus to study the effect of the duration of the treatment on baking quality. These samples of treated germ were added to flour at the level of $5 \%$ and baking tests were carried out with the results shown in Table XII.

\section{Table XII}

Baking Test on Samples Treated for Different Lengths of Time

\begin{tabular}{|c|c|c|c|}
\hline Treatment & $\begin{array}{l}\text { Protoolytic } \\
\text { Activity } \\
\text { of Germ } \\
\text { (units } / \mathrm{Kg}_{\mathrm{g}} \text { ) }\end{array}$ & $\begin{array}{l}\text { Losf } \\
\text { Volume } \\
\text { (ml.) }\end{array}$ & $\begin{array}{l}\text { Crumb } \\
\text { Colour } \\
\text { (relative } \\
\text { order) } \\
\end{array}$ \\
\hline Flour alone & - & 2650 & - \\
\hline 95\% flour alone (calculated) & - & 2510 & - \\
\hline Untreated wheat germ & 29 & 2500 & 4 \\
\hline $15 \min . \mathrm{s} \& 40 \mathrm{~min} \cdot \mathrm{N}$ & 13 & 2500 & 3 \\
\hline 20 min. $S \& 30$ Min. $N$ & 9 & 2500 & 3 \\
\hline 30 min. $s \& 45 \min . N$ & trace & 2575 & 2 \\
\hline 60 min. $\mathrm{s} \& 35 \mathrm{~min} . \mathrm{N}$ & nil & 2600 & 2 \\
\hline 25 min. $s \& 45$ min. A & " & 2600 & 1 \\
\hline
\end{tabular}

$\mathbf{S}=$ steam treatment at $105-110^{\circ} \mathrm{C}$.

$N=$ arying in current of nitrogen above $100^{\circ} \mathrm{C}$.

$\Lambda$ = arying in current of air above $100^{\circ} \mathrm{C}$.

The volume for $95 \%$ of flour alone is obtained by calculation and represents the volume that would be obtained if wheat germ was inert and occupied no volume. Actually the added 5\% of wheat germ occupies very little space. The loaves 
containing treated germ were not as brown an the outside and showed better symmetry than those with the untreated germ. The texture of all the loaves was about the same except that those made from "untreated" germ were very coarse and open. All the doughs containing "treated" germ appeared to be almost identical in handing quality and no excessive softening was noted in any of them. Table XII shows that:-

(1) treated wheat germ increases loaf volume whon its proteolytic enzymes are destroyed;

(2) there is a very marked correlation between baking quality and proteolytic deactivation;

(3) the destruction of the enzymes seems to be more rapid by drying in air than in nitrogen.

A baking test was similiarly carried out on the samples from Storage Test No. 5. The results of the storage test have been reported above and Table XIII gives the results of the baking test. The keeping qualities of the samples were perfectly correlated with baking qualities. 
Table XIII

Baking Test on Samples from Storage Test No.6

Treatment

Loaf volume in $\mathrm{ml}$.

Flour alone

2800

95\% flour alone (calculated)

2660

Untreated wheat germ

2250

30 min. S - $1 \mathrm{hr} \cdot \mathrm{D}$

2500

30 min. S - $1 \mathrm{hr} \cdot \mathrm{D}-\mathrm{NaCl}$

2350

15 min. $\mathbf{r}-15 \mathrm{~min} . \mathrm{s}-1 \mathrm{hr} . \mathrm{D}$

2575

15 min. $F-15$ min. $\mathrm{S}-1 \mathrm{Hr} . \mathrm{D}-\mathrm{NaCl}$

2475

$\mathrm{S}=$ steam treatment at $105-110^{\circ} \mathrm{C}$.

$\mathbf{I}=$ ethylene dichloride treatment at $95-100^{\circ} \mathrm{C}$.

D = arying in air

$\mathrm{NaCl}=2 \%$ of salt was added to the wheat germ before treatment and well incorporated during the treatment.

All of the loaves with treated germ were similar and quite acceptable in so far as crumb colour, symmetry and texture are concerned. The doughs containing "treated" germ appeared almost identical in handing quality. The loaf containing wheat germ treated with ethylene dichloride and steam was excellent. From Table XIII, it can be observed that:-

(1) the ethylene dichloride treatment was more desirable than the plain steam treatment;

(2) $2 \%$ of salt decreased the baking quality of the germ;

(3) the treatment made wheat germ suitable for baking 
bread, particularly if the loaf volume for the "95\% of the flour alone" value is accepted.

A thir baking test was carried out to determine the effect of storage on the baking quality of wheat germ; the samples used were from Storage Test No. 4 and had been stored for 8 months at $37^{\circ} \mathrm{C}$.

\section{Table XIV}

The fffect of Storage on the Baking Quality of Preated Wheat Germ

Plour control

95\% elour control (calculated)

2700

No. 1 (untreated)

2530

2500

No. 3 (ethylene dichloride and steam)

2475

No. 4 (steam only)

2525

Table XIV shows that after 8 months storage at $37^{\circ} \mathrm{C}$. the harmful effect of untreated wheat germ in baking bread was no longer evident if we compare the loaf volume with $95 \%$ of the control. There was no significant difference in the texture or crumb colour in any of these loaves. However, it must be remembered that the untreated sample was now spoiled.

III. The rffect of the Treatment on the Vitamin Content of Wheat Germ

Although the heat-treatment described above has been 
shown to give a product of good keeping quality it must also be shown that the excellent nutritive values of the fresh wheat germ are preserved. Among the dietary factors to be considered, the protein quality and the vitamin $F$ and $B_{7}$ content are most important.

The blological value of the wheat germ protein has been shown by Howe and Harrel (43) to be unaffected by heatprocessing.

For the determination of the vitamin $F$ content of the treated germ the crude-fat faction were extracted (52) from three samples of Storage Test No. 4 which had been stored 8 months at $37^{\circ} \mathrm{C}$. The crude-fat content of these samples amounted to $14 \%$ of the dry weight, indicating that there had been no appreciable removal of fat by the ethylene dichloride vapour. Vitamin $E$ determinations (58) on the crude fat from the treated and the raw germ showed that no $108 \mathrm{~s}$ was caused by the treatment.

The thiamin (vitamin $B_{1}$ ) content of the same samples was determined by the Thiochrome method as modified by Morrell (56), with the results shown in Table XV. 


\section{Table XV}

Thiamin Content of Wheat Germ Samples Stored for

8 months at $37^{\circ} \mathrm{C}$.

Treatment

$\frac{\text { Thiamin }}{(\mu \cdot g \cdot / 100 \text { g. ary wt. })}$

No.1 Untreated

224

No.3 Fthylene dichloride and steam treated 263

No.4 Steam treated

221

These data show that no thiamin was destroyed by the treatments, and suggests that the ethylene dichloride treatment has actually increased the retention of thiamin in storage. It is further indicated that, little loss occurred during storage, since these are high values for the thiamin content, of wheet germ produced by dry milling. According to Hinton (41), 1t is more difficult to extract the scutellum by dry miling and the soutellum contains ten times the thiamin content of the embryo. This excellent retention of thiamin in storage confirms the finding of Pearce (59).

Iy. Glutathione and the Activation of the Proteolytic marmes

\section{(a) Coneral}

Some experimental work was done in an attempt to explain the nature of the inactivation achieved by the heat treatment described above. Following the work of Tunnicliffe (73) some preliminary experiments were corried with methylene blue. 
They indicated that the untreated samples have a higher reducing power than the treated and the difference was particularly marked at the higher $\mathrm{pH}^{\prime} \mathrm{s}$. It was immediately suspected that the reducing power was due to the presence of glutathione which is the naturally occurring activator of papain. Although the reducing power of glutathione may be detected with methylene blue, this reaction is not sufficiently specific for a quantitative estimation. The well-established iodimetric method of Tunnicliffe (72) and the Nitroprusside Test of Fleming (28) were considered, together with their various modifications, but these also lacked the necessary specificity. It was finally decided to use the method of Binet and Weller $(17,18,78)$ which is based on the quantitative precipitation of glutathione by cadmium lactate and determination of the glutathione in the precipitate by iodimetry.

\section{(b) The Estimation of Glutathione in Wheat Germ}

(1) Procedure: A 1-8. portion of wheat germ was carefully ground in a mortar with $5 \mathrm{ml}$. of $95 \%$ ethanol for one minute, then $10 \mathrm{ml}$. of a $10 \%$ solution of trichloracetic acid were added and the solution filtered through a Whatman 42 paper into a 50-ml. volumetric flask. The mortar was rinsed and the filter extracted three times with 10-ml. portions of trichloracetic acid and then the filtrate was made up to volume in the volumetric flask. Two $20-\mathrm{ml}$. aliquots were placed in 50-ml. centrifuge tubes, 5 drops of bromothymol blue were added and the $\mathrm{pH}$ was adjusted to a faint blue tinge, first by the addition of $25 \%$ sodium hydroxide until close to 
the end-point and then with $0.5 \%$ sodium hydroxide. One allquot was used for the estimation of the reduced glutathione and the other for the total glutathione. To the latter was added $1 \mathrm{ml}$. of $5 \%$ sodium cyanide, the solution allowed to stand for 30 minutes and then $3 \%$ cadmium lactate in $0.1 \%$ acetic acid was added until a green or yellow colour developed. At this point $2 \mathrm{ml}$. of $2 \%$ cadmium lactate were added to both tubes and the $\mathrm{pH}$ was adjusted with $0.5 \%$ sodium hydroxide to the first blue colour of the indicator and a white flocculent precipitate of cadmium glutathionate was formed. After standing two hours the tubes were centrifuged, the supernatant liquid was decanted by quickly inverting the tube and the interior of the tube was dried with a filter paper rolled around a glass rod. The precipitate was then dissolved in $10 \mathrm{ml}$. of $10 \%$ phosphorlc acid, $5 \mathrm{ml}$. of lodine solution were added and, after two minutes, 5 drops of starch indicator were added and the mixture was back-t1trated w1th exactly 0.002 normal sodium thiosulphate. A blank determination was made at the beginning and end of a serles of determinations by titrating $5 \mathrm{ml}$. of lodine solution in 10 ml. of $10 \%$ phosphoric acid containing 5 drops of starch indicator, with sodium thiosulphate using exactly the same technique. The value, mg. of glutathione per $100 \mathrm{~g}$. of wheat germ is calculated as follows:-

$\frac{2 n \times \text { m.w. }}{W} \times \frac{V}{A} \times \frac{100}{1000}=n \times 153.5$

$n=m l$. of 0.002 normal thiosulphate-difference between blank and test solution 


$$
\begin{aligned}
& \text { m.W०= molecular weight of glutathione (307) } \\
& W \text { = weight of sample ( } 1 \mathrm{~g} \cdot) \\
& v \text { = volume of dilution }(50 \mathrm{ml} .) \\
& A \text { = volume of aliquot }(20 \mathrm{ml} .)
\end{aligned}
$$

The difference between the total and the reduced glutathione gives the oxidized glutathione.

(2) Brtraction: The use of $95 \%$ ethanol was introduced in the extraction because it facilitated the penetration of the solvent. Trichloracetic acid was chosen as the solvent because of its traditional use in the determination of glutathione and because satisfactory results were obtalned with it. Alternative reagents such as tungstate formed a precipitate with cadmium and sulphosallcilic acid gave high and erratic results. Glutathione decomposes in neutral and alkali solutions, but it is fairly stable at a low pH such as in the 10\% trichloracetic acid. It was found that extracting 18 . of wheat germ with three 10-ml. portions of trichloracetic acid gave maximum recovery. Further extraction with trichloracetic acid actually reduced the apparent amount of glutathione, probably because of difficulty in handing the larger volume.

(3) Precipitation: Voegtlin, Johnson and Rosenthal's (76) method for precipitating glutathione with cadmium acetate gave them an excellent yield of a copper-free product. Cadmium lactate was used in this work because it has been found to be more specific and to give more nearly quantitative precipitation (17). It was prepared as follows:- 
4 known amount of cadmium carbonate was dissolved in an excess of dilute hydrochloric acid and the solution made alkaline with concentrated sodium hydroxide. The fine white precipitate of cadmium hydroxide which formed, was washed a few times with distilled water and with centrifuging. It was then dissolved in a slight excess of lactic acid and, after removing most of the water, absolute ethanol was added to form a flocculent white precipitate of cadmium lactate which was then washed twice in alsolute alcohol and dried.

The precipitation of cadmium glutathionate starts at $\mathrm{pH}$ 6.2 and was quantitatively completed at pH 6.8. This precipitation is highly specific and there is no interference by ascorbic acid or ergothionelne (17). Furthermore, it was clearly shown by the following experiment that, above pH 6.2, there was no interference by cysteine (17). The extract, prepared as described above was adjusted to $\mathrm{pH} 6.2$ and $1 \mathrm{ml}$. of $2 \%$ cadmium lactate was added. The precipitate, which formed after one hour, was separated by centrifuging; the supernatant liquid was adjusted to $\mathrm{pH} 6.8$ and the glutathione determined in the precipitate. The results were not significantIy different from those obtained by the usual procedure, so no correction need made for the cysteine content of wheat germ. Quantitative precipitation of glutathione was confirmed with a solution of pure glutathione and by the recovery of known amounts of glutathione added to an extract of wheat germ (see Table XVI). 


\section{Table XVI}

The Recovery of alutathione by Precipitation with Cadmium Lactate

I mg o glutathione

1.0

1.02

102

Extract of 18 . wheat germ

$\begin{array}{lll}- & 1.06 & - \\ 2.06 & 2.04 & 99\end{array}$

Bxtract of $1 \mathrm{~g}$. wheat germ \& 1 mg. glutathione

Ixtract of $1 \mathrm{~g}$. wheat germ \& $2 \mathrm{mg}$. glutathione

$3.06 \quad 3.14$

103

(4) Titration: The results in Table XVI also confirm the accuracy of the lodimetry. The solution of lodine was prepared from a saturated aqueous solution of pure lodine which had been allowed to stand in the dark for 2 - 3 days.

Potassium lodide was not used because, according to Binel and Weller (17), it interferes in the glutathione determination and in peliminary tests we found that satiafactory duplicates could not be obtained. However, when prepared in thls manner, the normality of the lodine solution increased slightly on standing (approaching 0.002 normal), so that it was necessary to make blank determinations with each analysis. An 0.1 normal solution of sodium thiosulphate was restandardized each week and used dally to check the 0.002 normal solution of lodine.

$\frac{\text { (c) The Iffect of Treatment of the Germ on its Glutathione }}{\text { Content }}$

Samples from Storage Test No. 5 whlch had been held 
8 months at $37^{\circ} \mathrm{C}$. were analyzed for their glutathione content. Table XVII gives the averages of quadruplicate determinations.

\section{Table XVII}

The Glutathione Content of Treated Wheat Germ

Treatment

$$
\frac{\text { Glutathione }(\mathrm{mg} / \mathrm{l} / \mathrm{gg} \cdot)}{\text { Total }}
$$

(by difference)

No.1 Untreated

$147 \cdot 4$

102.6

44.8

No.3 Fthylene dichloride

76.7

77.2

n11

No.4 Steam

79.8

80.5

nil

These results indicate that the treatment reduced the total glutathione by $50 \%$ and the reduced glutathione by $25 \%$ with complete destruction of the oxidized glutathione. This would signify that the treatment carried the oxidation of glutathione beyond the dithio-configuration, possibly causing complete decomposition and certainly bringing about a change which is not reversed by sodium cyanide.

\section{(d) Reactivation of the Proteolytic Enzymes by Glutathione and Cranide}

According to Bergmann, glutathione or a simllar activator is essential in the activation of papaln-like enzymes. By adding glutathione to the digest of treated wheat germ, as prepared for the determination of proteolytic activity, it should be possible to determine whether the reduced enzymatic activity was due to the destruction of glutathione or to 
denaturation of the protein-enzyme. The results of such an experiment are given in Table XVIII. The proteolytic activity of the samples from Storage Test No.7 was determined with and without added activators.

\section{Table XVIII}

The Iffect of Activators on Proteolytic Activity of Wheat Germ

Activator

Proteolytic Activity (units/ $\mathrm{Kg}_{\mathrm{g}}$ ) Sample No.I Sample No. 3 Sample No. 4 Untreated Fthylene DiSteam Treated chloride Treated

$\mathrm{N} 11$ - control

$0.5 \mathrm{mg} \cdot$ glutathione

$1.0 \mathrm{mg} \cdot$ glutathione

$0.25 \mathrm{mg} \cdot$ sodium cyanide
31

6

n11

31

22

31

28
28

28
11

"

II

Apparently the steam treatment denaturated the proteolytic enzymes so that they are not reactivated by glutathione or cyanide, whereas the enzymes in the ethylene dichloride-treated wheat germ are almost completely reactivated by glutathione or cyanide. Activation by cyanide indicater that the papainIike enzyme was changed by the treatment to the reduced inactive form (the $\beta$ form according to Bergmann's Theory). To restore the activity of the treated germ to the level of the raw germ required the addition of almost five-times the quantity of glutathione actualiy destroyed by the treatment. Since the addition of glutathione to the untreated germ did not increase its activity it would appear that the optimum 
amount was already present. The effect of cyanide on the activity of untreated germ might be due to the poisoning of some related enzyme systems containing heavy motals. 
PART D

DISCUSSION 
I. The Importance of Peroxide Content and Lipoxidase Activity to the Keeping Qusilty and Baking Properties of Wheat Germ

Pearce (59) had already shown that the peroxide formation during the storage of raw wheat germ was very small but the effect of heat treatment was not known. It might retard peroxide formation by the destruction of lipoxidase activity; or it might accelerate the formation of peroxide by destroying some naturally occurring antioxidants or by catalyzing the initial oxidation. It was found that all the treatmente destroyed the Iipoxidase activity but when the treatment was carried out in air the retardation of peroxide formation was overshadowed by an opposing effect increasing the peroxide content; however when the treatment was carried out in nitrogen the latter effect was minlmized so that a slight retardation of peroxide development became apperent.

Using the Chapman and McFarlane method (64), which is much more sensitive than most of the other tests for peroxide, rancidity was detected at a peroxide content of about 20 milliequivalents per $\mathrm{kg}$. of wheat germ. This level was only reached under conditions extremely favourable to rancidity and therefore is unlikely to be a serious problem in the storage and shipment of wheat germ. However, Sullivan et al. (70) showed, that the presence of the oxtalzed unsaturated fatty aoids of wheat germ had an adverse effect in baking quality so in the industrial production of wheat germ it may be important to prevent oxidation of the product. This may be done by a short heat treatment in an inert atmosphere. 


\section{Proteolytic Inzymes and the Keeping Quslity and Baking Properties of Whoat Germ}

The development of off-flavours in the storage of wheat germ due to protein breakdown was shown to be a more serious problem than rancidity. This was indiceted by the influence of moisture on spoilage during storage and more directly by the relationship between proteolytic activity and keoping quality. Improved keeping and baking qualities resulted from the denaturation of the enzymes and/or by the oxidation of the activator, glutathione, beyond the dithio-form. Ethylene dichloride vapour is particularly effective in oxidizing glutathione and also serves to remove volatile odoriferous substances and molsture. The fact that this treatment improves the baking quality as effectively as the steamtreatment indicates that glutathione is the main factor affecting the baking quality of untreated germ. This also suggests that the improved baking quality of untreated germ after prolonged storage, is due to the oxidation of glutathione.

It is interesting to note that sodium cyanide had a slight poisoning effect on the proteolytic enzymes of raw wheat germ because 1 indicates a possible link between the papain-like enzyme and the heavy-metal enzyme system. Although the effect was small it was consistent and further work should lead to a better understanding of the two enzyme systems. 


\section{The Importance of the Treatment}

Two methods of improving the baking quality of wheat germ have been proposed in recent literature. One is the steeping of the wheat germ before use, but it is claimed by other workers that this does not improve baking quality and that it removes valuable constituents such as the watersoluble vitamins. The other proposed method is to use prefermented germ as the fermenting agent in the dough. This seems practical and cheap, but fermented germ would not also be utilizable as a cereal.

A wheat germ of excellent quality is now marketed under the trade name "Tonik" Wheat Germ, but this product also has its disadvantages. It can only be used as a cereal and not in bread baking. The fat fraction of the germ has been removed, and with it the fat-soluble vitamin $E$; the palatability and food value are also reduced. The cost of the product is high and the facilities for its production under war conditions are limited. Furthermore, the expansion of production when materials become available will require a large capital investment with uncertain reduction in price since there is no good market for large quantities of the oll.

If by some simple changes in the equipment used in this study, a wheat germ of the desired quality could be produced, the price of the product would not be much higher than raw wheat germ. It is believed that it would be a simple matter to design commercial equipment, based on the present studies, which would produce a low-priced product of high nutritive value 
with good baking and keeping qualities. For this reason it is felt that the process here developed could play an important part in solving some of the food problems that will arise after the war. 
PART $\mathbf{E}$

SUMMARY 
(1) An adaptation of Sumner's method for the determination of Iipoxidase activity in wheat germ has been developed.

(2) A short and simple method for the determination of proteolytic activity is presented.

(3) The method of Binet and Weller for the estimation of glutathione has been studied. It is found to be highly specific and with certain minor modifications it gives consistent results.

(4) These three analytical procedures have been used in this investigation on wheat germ, from the results of which the following canclusions would appear warranted:-

(a) If poxidase activity is not related to peroxide formation or keoping quality and the formation of peroxides is not related to the development of offflavours.

(b) Wheat germ heated in air develops, in storage, a highor content of peroxide than wheat germ similarly heated in nitrogen. The development of peroxide in treated wheat germ during storage was not found to depend on the nature of the gas used in packing.

(c) Proteolytic activity is correlated with keeping and baking qualities of wheat germ. Molst heat is necessary to destroy proteolytic activity but the molsture content of the final product must not exceed $5 \%$ for good keeping quality.

(d) The passage of gaseous ethylene dichloride, chloroform, or steam through the germ was found to improve its 
palatability and keoping quality, probably by the removal of some odoriferous volatile substances. In a mild treatment of 15 to 30 minutes ethylene dichloride is more effective than steam, but in longer treatments of 1.5 to 2 hours both are equally effective. The last traces of solvent were easily removed by steam. The treatment destroys $50 \%$ of the total glutathione, $25 \%$ of the reduced glutathione and all the oxidized glutathione. The good keeplng and baking qualities of the ethylene dichloride treated sample are attributed to the partial destruction of glutathione. The steam treatment destroyed about the same amount of glutathione but also denatured the proteolytic enzyme.

(e) The addition of $2 \%$ salt, before processing improved the palatability of the fresh product, but reduced its keeping and baking qualities.

(f) A very sat1sfactory laboratory-scale, glass apparatus, was developed for treating of wheat germ which gave a product of excellent keeping and baking qualities. 11-metal equipment was also designed and constructed for the small scale production of treated wheat germ which showed possibility of Industrial development.

(g) Bxcellent biscuits and bread were made with treated wheat germ.

(h) Vitamins $F$ and $B_{1}$ content of the germ was not reduced by the treatment. 
PART F

BIBLIOGRAPHY 
1. Anson, M.L.,

The Estimation of Papain with Hemoglobin

J. Gen. Physiol. 30:561 (1936-37)

2. Balley, C.H.,

Germ Content of American Wheats

Cereal Chem. 15:102 (1938)

3. Balls, A.K. and Hale, W.S.,

Proteolysis in Flours

J. ABs. O. Agr. Chem. 18:135 (1935)

4. Balls, A.K. and Hale, W.S.,

Proteolytic Enzymes in Flour

Cereal Chem. 13:54 (1936)

5. Balls, A.X. and Hale, W.S.,

Further Studies on the Activity of Proteinase in Flour

Cereal Chem. 13:656 (1936)

6. Balls, A.K. and Halo, W.S.,

Properties of Wheat Proteinase

Cereal Chem. 15:622 (1938)

7. Balls, A.K. and Lineweaver, H.,

Isolation and Properties of Crystalline Papain

J. Biol. Chem. 130:669 (1939)

8. Balls, A.K., Swenson, T.L. and Stuart, L.S.,

Assay of Papain

J. Ass. O. Agr. Chem. 18:140 (1935)

9. Barron, E.S.G. and Singer, T.P.,

The Role of Glutathione

Sclence 97:356 (1943)

10. Behrens, O.K. and Bergmann, M., Cosubstrates in Proteolysis

J. B101. Chem. 129:587 (1939)

11. Bergmann, M., Classification of Proteolytic Enzymes

Advances in Inzymology (Interscience)Vol.2, page 63 (1942)

12. Bergmann, M., Fruton, J.S. and Pollok, H., The Specifleity of Trypsin

J. B101. Chem. 127:643 (1939)

13. Bergmann, M., Zervas, L. and Fruton, J.S.,

$X I$. The Specificity of the Enzyme, Papain-Peptidase I

J. B101. Chem. 115:593 (1936) 
14. Bergmann, M., Zervas, L. and Ross, W.F., VII. The Sunthesis of Poptides of I-Lysine and Their Behavior with Papain. J. B101. Chem. 111:245 (1935)

15. Bersin, T.,

The Action of Oxidizing and Reducing Agents on Papain Z. Physiol. Chem. 222:177 (1934) - C.A. 28:1367 (1934)

16. Bersin, T. and Logemann, W., The Influence of Osidizing and Reducing Agents on the Activity of Papain

Z. Physiol. Chem. 220:209 (1933) - C.A. 27:5760 (1933)

17. Binet, L. and Weller, G., Le Dosage du Glutathion Réduit dans les Tissus Bull. Soc. Chim. Biol. 16:1284 (1934)

18. Binet, L. and Weller, G., Méthode de Dosage du Glutathion dans les Tissus, sous sa Forme Réduite et sous sa Forme oxydée Compt. Rend. Soc. Biol. 69:939 (1935)

19. Brown, A.H. and Goddard, D.R., Cytochrome Oxidase in wheat Germ Am. J. Botany 28:319 (1941)

20. Bull, G.E.,

An Investigation into the Cause of the Degrading Effect of Wheat Germ on the Baking Quality of Flour

Cereal Chem. 15:244 (1937)

21. Cairns, A. and Bailey, C.H., Proteoclastic Activity in Flour Cereal Chem. 5:79 (1928)

22. Chapman, R.A. and McFarlane, W.D., Estimation of Fat-Peroxides in Milk Powders Can. J. Res. 21: sec.B:133 (1943)

23. Crampton, E.W. and Ashton, G.C., The Role of the Germ in the Nutritive Properties of the Cereal Grains Sci. Agr. 23:455 (1943)

24. Denham, H.S. and Blair, G.W.S., Proteolytic Activity of Flour Cereal Chem. 4:58 (1927)

25. Donk, P.G. and MacDonald, A.R., Preserving Wheat Germ Brit. 436,765 Oct.17 (1935) - C.A. 30:1890 (1936) 

26. Donk, P.G. and MacDonald, A.R. for Use in the Manufacture
Stabilized Wheat Germ Product for of Bakery Products U.S. 2,085,421, June 29 - C.A. 31:5894 (1937)

27. Elion, E., The Action of Glutathione and Wheat Germ on Dough in Relation to Proteolytic Inzymes in Wheat Flour Cereal Chem. 20:234 (1943)

28. Fleming, R., Determination of Glutathione by a Colorimetric Method Compt. Rend. Soc. B101. 106:259 (1931)

29. Flohil, J.T.,

The Effect of Chemlcal as Flour Improvers on Proteolytic Action in Relation to the Gas-Retaining Capacity of Fermenting Doughs

Cereal Chem. 13:675 (1936)

30. Folin, 0. and Ciocalter, V., On Tyrosin and Triptophane Determinations in Protein J. Biol. Chem. 73:627 (1927)

31. Ford, W.P. and Malden, A.M., Effects in Dough of GIutathione and Papain

J. Soc. Chem. Ind. 57:278 (1938)

32. Frankel, E.M.,

Proteolytic Activity or Papain

J. B101. Chem. 31:201 (1917)

33. Fruton, J.S. and Bergmann, M., The Activation of Papain

J. Biol. Chem. 133:153 (1940)

34. Goddes, W.F.,

The Influence of Germ Constituents on Baking Quality and Their Relation to Improvement in Flour Induced by Heat and Chemical Improvers

Can. J. Res. 2:195 (1930)

35. Gortner, R.A.Jr., and Gunderson, F.L.,

Proteins in Human Nutrition

Ind. Fng. Chem. (News Edition) 22:160 (1944)

36. Grewe, E. and Leclerc, J.A., Commercial Wheat Germ. Its Composition

Cereal Chem. 20:423 (1943)

37. Grewe, E. and LeClerc, J.A.,

Wheat Germ in Bread Making

Cereal Chem. 20:434 (1943) 
38. Hertwig, R., M1ldly Toasted Wheat Germ - A Possible Merohandisable Table Coreal

Cereal Chem. 8:226 (1931)

39. Hertwig, R.,

A Toasted Wheat cerm Self-Rising Flour - A PosBlble

Merchandisable Cereal

Cereal Chem. 8:229 (1931)

40. H111s, C.H. and Ba1ley, C.H.,

The Nature of the Increase in Amylase Activity of Germinating Barley

Coreal Chom. 15:273 (1938)

41. Hint on, J.J.C.,

V1tamin $B_{1}$ and $B_{2}$ Contents of Wheat Germ

J. Soc. Chem. Ind. 61:143 (1942)

42. Hopkins, F.G.,

On Glutathione

J. B10l. Chom. 84:269 (1929)

43. Hove, E.I. and Harrel, C.G., The Nutritive Value of Wheat Germ Protein

Cereal Chem. 20:141 (1943)

44. Hullet, E.W. and Stern, R.,

Biological Elimination of Glutathione from Wheat Germ and Flours used in Bread Making

Ceres l Chem. 18:561 (1941)

45. Jansen, E.F. and Balls, A.K.

Chymopapain - A New Crystalline Proteinaso from Papaya

Latex

J. B101. Chem. 137:459 (1941)

46. Jorgensen, H.,

Ein Beltrag zur Belouchtung der hemmenden Wifkung von oxydations mitteln auf proteolytische inzymtatigkeit B10chem. Z. 280:1 (1935)

47. Jórgensen, H.,

Baking Strength of Whoat Flour

Cereal Chem. 16:51 (1939)

48. Kendall, E.C., MaKenzie, B.F. and Mason, H.L., A Study of Glutathione

J. B101. Chem. 84:657 (1929)

49. Meldrum, N. and Dixon, M., Properties of Glutathione B1ochem. J. 24:472 (1930) 
50. Melv1lle, J. and Shattock, H.T., The Action of Ascorbic Acld as a Bread Improver Cereal Chem. 15:201 (1938)

51. Mendel, L.B. and Blood, A.F.,

Papain Proteolysis

J. Biol. Chem. 8:177 (1910)

52. Mothod of Analye1s of Ass. O. Agr. Chem. Crude Fat Determination - Fifth Edition, page 356

53. Method of Analysis of Ass. O. Agr. Chem. Washed Sand - Fifth Edition, page 390

54. Morgan, A.F. and Frederick, H., V1tamin $B$ ( $\left.B_{1}\right)$ in Bread as Effected by Baking Cereal Chem. 12:390 (1935)

55. Morgan, A.F. and Hunt, M.J., The Vitamin $B\left(B_{7}\right)$ and $G\left(B_{2}\right)$ Content of wheat Products Cereal Chem. 12: 411 (1935)

56. Morrell, C.A.,

A Modification of the Thiochrome Method for Thiamin

Determination

Private Communication, Laboratory of Hygiene, Department of Pensions and National Health, Ottawa.

57. Munsell, H.E. and De Veney, G.M., Vitamins $B$ and $G$ Content of Wheat Germ

Cereal Chem. 10:287 (1933)

58. Parker, W.F. and McFarlane, W.D.,

A Proposed Modification of Emmerie's Iron-Dipyridyl Method for Determining the Tocopherol Content of $011 \mathrm{~s}$

Can. J. Res. 18: sec.B: 405 (1940)

59. Pearce, J.A.,

Effect of Storage on Thiamin Content and on Development of Rancidity in Wheat Germ

Can. J. Res. 21: Bec.c:57 (1943)

60. Quastel, J.H. and Wheatley, A.H.M.,

Relation of Thiol Compounds to Glucose Fermentation

B10chem. J. 26:2169 (1932)

61. Regnier, M.T.,

Proparation du Glutathion

J. Pharm. Chim. 18:369 (1933)

62. RICh, C.E., Chemical Changes in wheat Flour Cereal Chem 11:225 (1934) 
63. Schuette, H.A. and Palmer, R.C., The Chemistry of the Rye Germ: IV. Its Proximate Composition

Cereal Chem. 15:445 (1938)

64. Shen, T. and Geddes, W.F., Baking Behavior of Doughs Cereal Chem. 19:609 (1942)

65. Sm1th, D.E. and Geddes, W.F., Yeast Fermentation and Potassium Bromate as Factors Influencing Harmful Effects of Wheat Germ on Baking Quality

Cereal Chem. 19:785 (1942)

66. Stern, R., Iffects of Wheat Germ Extracts on Doughs Cereal Chem. 21:81 (1944)

67. Sullivan, B. and Howe, M., The Isolation of Glutathione from Wheat Germ. J. Am. Chem. Soc. 59:2742 (1937)

68. Sullivan, B., Howe, M. and Schmalz, F.D., On the Presence of olutathione in Wheat Germ Cereal Chem. 13:665 (1936)

69. Sullivan, B., Howe, M., Schmalz, F.D. and Astleford, G.R., The Action of Oxldizing and Reducling Agents on Flour Cereal Chem. 17:507 (1940)

70. Sullivan, B., Noar, C. and Foley, G.H., The Role of the Lipids in Relation to Flour Quality Cereal Chem. 13:318 (1936)

71. Sumner, R.J., Llpoid Oxidase Studies

Ind. Ing. Chem., Anal. Ed., 15:14 (1943)

72. Tunnicliffe, H.E.,

The Occurrence and Quantitative Estimation of Glutathione in Tissues

B1ochem. J. 19:194 (1925)

73. Tunnicliffe, H.I.,

Relation between the Tissues and the Oxidized D1peptide Blochem. J. 19:199 (1925)

74. Vines, S.H., Proteolytic Enzymes in Plants Ann. Bot. 17:602 (1903) 
75. VioBin Corporation, Montecello, Ill. Private Communication

76. Voegtlin, C., Johnson, J.M. and Rosenthal, S.M., The Oxidation Catalysis of Glutathione J. Biol. Chem. 93:435 (1931)

77. Wanklyn, K.P. and Stacoy, F., Wheat Germ Food

Brit. 332,847, Oct. 31 (1929) - C.A. 25:546 (1931)

78. Weller, J., Sur le Dosage de Glutathion dans la Levure Ann. Fermentations 1:108 (1935)

79. Winnick, T., Davis, A.R. and Greenberg, D.M., Studies on Asclepain

J. Gen. Physiology 23:275, 301 (1939-40)

80. Yule, J.A.C. and Wilson, C.P., Peroxides and Gum in Gasoline

Ind. Fng. Chem. 23:1254 (1931)

81. Ziegler, E., Oxidation of Glutathione by Bromate Cereal Chem. 17:460 (1940)

82. Zlegler, E., Oxid1zed Glutathione in Bread Cereal Chem. 17:551 (1940) 

